\title{
Improving Human Health with Milk Fat Globule Membrane, Lactic Acid Bacteria, and Bifidobacteria
}

\author{
Erica Kosmerl (D), Diana Rocha-Mendoza, Joana Ortega-Anaya (D), Rafael Jiménez-Flores *(D) \\ and Israel García-Cano *iD
}

Citation: Kosmerl, E.

Rocha-Mendoza, D.; Ortega-Anaya, J.; Jiménez-Flores, R.; García-Cano, I. Improving Human Health with Milk Fat Globule Membrane, Lactic Acid Bacteria, and Bifidobacteria. Microorganisms 2021, 9, 341. https://doi.org/10.3390/ microorganisms 9020341

Academic Editor: Thu Ha Nguyen Received: 31 December 2020

Accepted: 5 February 2021

Published: 9 February 2021

Publisher's Note: MDPI stays neutral with regard to jurisdictional claims in published maps and institutional affiliations.

Copyright: (c) 2021 by the authors. Licensee MDPI, Basel, Switzerland. This article is an open access article distributed under the terms and conditions of the Creative Commons Attribution (CC BY) license (https:// creativecommons.org/licenses/by/ $4.0 /)$.
Department of Food Science and Technology, The Ohio State University, Columbus, OH 43210, USA; kosmerl.3@buckeyemail.osu.edu (E.K.); rochamendoza.1@osu.edu (D.R.-M.); ortegaanaya.1@osu.edu (J.O.-A.) * Correspondence: jimenez-flores.1@osu.edu (R.J.-F.); garciacano.1@osu.edu (I.G.-C.)

\begin{abstract}
The milk fat globule membrane (MFGM), the component that surrounds fat globules in milk, and its constituents have gained significant attention for their gut function, immune-boosting properties, and cognitive-development roles. The MFGM can directly interact with probiotic bacteria, such as bifidobacteria and lactic acid bacteria (LAB), through interactions with bacterial surface proteins. With these interactions in mind, increasing evidence supports a synergistic effect between MFGM and probiotics to benefit human health at all ages. This important synergy affects the survival and adhesion of probiotic bacteria through gastrointestinal transit, mucosal immunity, and neurocognitive behavior in developing infants. In this review, we highlight the current understanding of the co-supplementation of MFGM and probiotics with a specific emphasis on their interactions and colocalization in dairy foods, supporting in vivo and clinical evidence, and current and future potential applications.
\end{abstract}

Keywords: gut microbiota; infant formula; milk fat globule membrane; dairy foods; interactions

\section{Introduction}

The milk fat globule membrane (MFGM) is the structure comprised of lipids, membraneassociated proteins, and carbohydrates in the form of glycoconjugates, which surround every fat globule secreted in milk during lactation of mammals. The beneficial impacts of the bovine MFGM have been well-established [1]. In recent years, infant formula companies have begun to include MFGM ingredients in their formulations for its effects on cognitive development and gut maturation [2,3]. Furthermore, the focus on understanding how MFGM affects the gut microbiome of developing infants is gaining momentum. The current evidence demonstrates that MFGM supplementation increases the abundance of beneficial bacteria, such as bifidobacteria and some species of lactic acid bacteria (LAB), which is associated with a reduced risk of several diseases, including type I and type II diabetes, hepatitis B, and obesity (previously reviewed in [1]). However, the mechanism by which the MFGM imparts its benefits is much more poorly understood. In addition to the benefits of MFGM consumption, probiotics and their positive outcomes go beyond intestinal and immunological health by also directly impacting cognitive function. In this review, we aim to concisely summarize the current research on the MFGM and its interactions with probiotics both in foods and the gastrointestinal tract and discuss the potential mechanisms involved with their interactions, as well as the synergistic effects of co-supplementation.

\subsection{The Milk Fat Globule Membrane \\ 1.1.1. Structure and Origin}

To comprehend the complex structure and composition of the MFGM, it is necessary to understand its origin. The MFGM originates in the secretory cells of the mammary gland alveoli (Figure 1). Once the fat globules are synthesized in the rough endoplasmic 
reticulum (ER), they are coated with a first layer of phospholipids before being released to the cytoplasm [4]. They migrate to the apical part of the cell, where they are enveloped with an additional bilayer of phospholipids derived from the cell membrane and then expelled into the alveolar lumen [5]. During secretion, an additional layer that is electron density rich forms between the outer bilayer and the monolayer, which houses cytosolic proteins xanthine dehydrogenase/oxidase $(\mathrm{XDH} / \mathrm{XO})$ and the FABP family [6,7], as well as $\mathrm{ADPH}$ which is embedded in the phospholipid monolayer (Figure 1, insert). $\mathrm{XDH} / \mathrm{XO}$ is colocalized with a small extracellular region of integral membrane protein BTN from the moment they are synthesized in the apical part of the secretory cells, as observed experimentally in mouse models [8]. The role of the MFGM during lactation is one of active participation in the secretion of fat globules. After lactation, it prevents the coalescence of fat droplets by maintaining the milk emulsion and serving as a barrier to avoid lipase and other enzymatic activity that could disrupt the globules [9].

\subsubsection{Composition}

The gross composition of the MFGM varies greatly as a result of factors such as the physiology of the mammal, isolation and purification methods, processing of the milk, and even the analytical techniques used to quantify the molecular components (Table 1). In general, the concentration of MFGM in cream ranges between 3.0-3.9 g/L and is composed primarily of specific lipids and membrane-associated proteins that, together, account for over $90 \%$ of the MFGM dry weight.

As shown in Table 1, the MFGM is rich in lipids, the predominant class being milk phospholipids (MPLs) (Table 2). Phospholipids (PLs) are ubiquitous molecules in membranes and vesicles, and the MFGM possesses a unique mixture not found in plant-based lecithin. Phosphatidylethanolamine (PE) is usually found as an important constituent of nervous and brain tissue and, in the MFGM, constitutes up to $46 \%$ of the total MPLs [14], whereas phosphatidylcholine (PC) represents up to $38 \%$, and its function is to maintain the permeability of the membrane due to its flexible morphology $[15,16]$. Phosphatidylinositol (PI) and phosphatidylserine (PS) are present in lower concentrations in milk and are anionic PLs distributed asymmetrically throughout the MFGM [17]. Sphingomyelin (SM) is the main sphingolipid in the MFGM due to its high concentration (about 30-40\%), and it is known to have many beneficial effects on human health, such as improved neuronal development in infants and the protection of neonates from bacterial infections [18-20]. Structurally, SM forms lipid-ordered domains that also contain cholesterol (Figure 1B). This cholesterol appears to be involved not only in the topography and fluidity of the MFGM but, also, in biological functions such as localization and insertion of MFGM proteins with transmembrane domains [21-23]. The MFGM lipids are arranged asymmetrically in such a specific way that SM and PC are located on the outside of the bilayer while PE, PS, and PI are found inside the membrane [15]. MFGM glycolipids are almost exclusively located in the outer layer [24].

The composition of the MFGM components varies greatly between mammalian species. Even though the structure and biosynthesis are similar, the profile of MPLs is different, as seen in Figure 2. The composition of human MPL in comparison to bovine milk differs mainly in the concentration of SM and PS-human milk provides a higher percentage of SM, whereas bovine milk has a higher percentage of PS. The composition of MPLs from donkey milk is extremely different from that of milk of all other species, particularly due to the high values of PE and the low values of SM.

Gangliosides are glycolipids involved in neuronal development and immunological adaptation in neonates and, hence, are very important in human nutrition. GD3 is the main ganglioside in bovine and human MFGM, followed by GM3, although the concentrations are different [25]. 


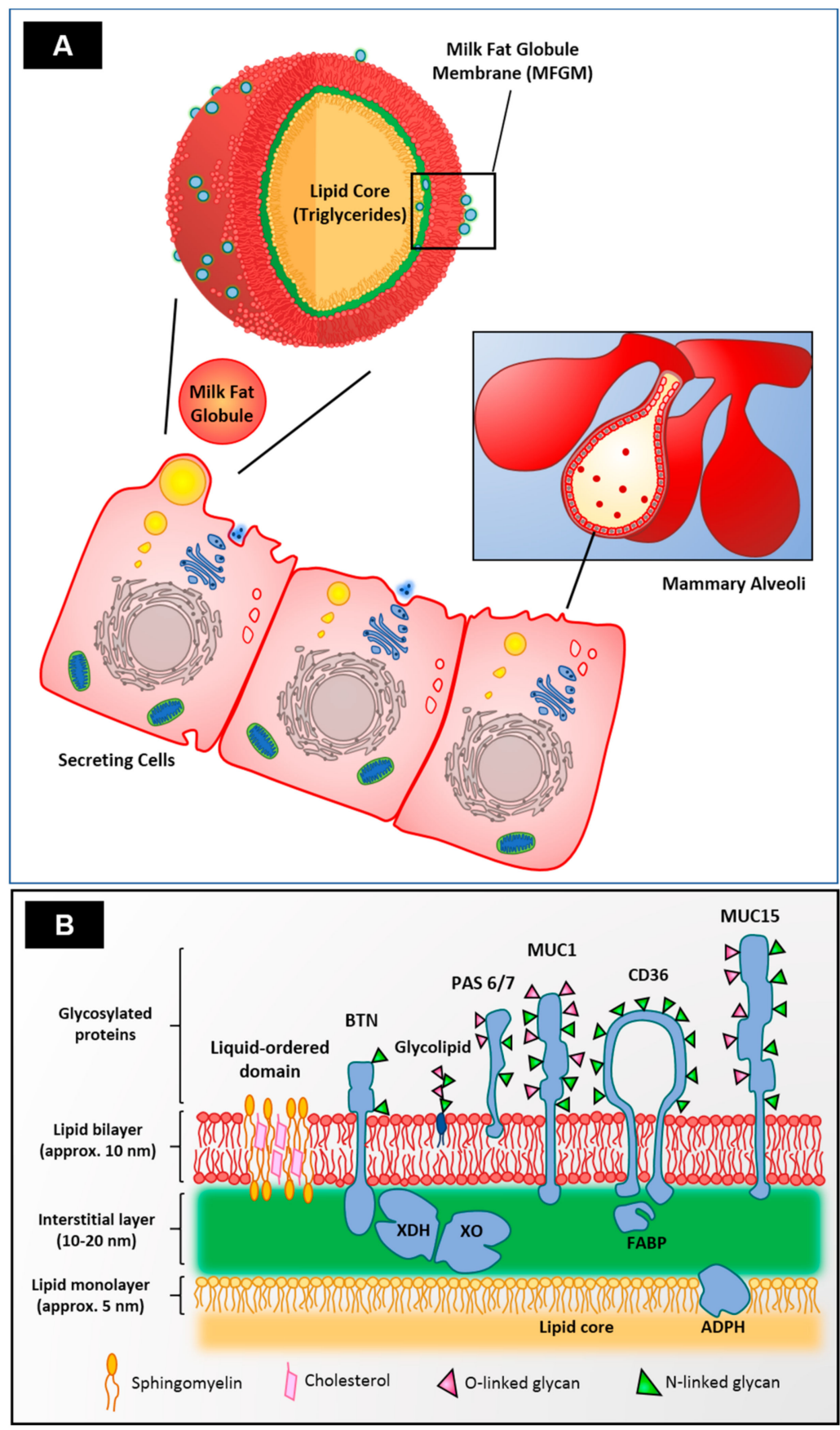

Figure 1. Schematic diagram of (A) the biosynthesis of fat globules during lactation and (B) the structure of the milk fat globule membrane (MFGM) where the different layers and their general compositions are depicted. BTN, Butyrophilin; PAS 6/7, Lactadherin; MUC-1, Mucin 1; CD36, Cluster of differentiation 36; MUC-15, Mucin 15; XDH/XO, Xanthine dehydrogenase/oxidase; FABP, fatty acid binding protein family; and ADPH, Adipophilin. Adapted with permission from Ortega-Anaya et al. (2020). Copyright 2020 Elsevier Ltd. [7]. 
Table 1. General composition of the milk fat globule membrane (MFGM). Data compiled from [10-13].

\begin{tabular}{cc}
\hline Component & Concentration Range (\%) \\
\hline Lipids & $64-71.8$ \\
Protein & $22.3-28$ \\
Glycoconjugates & 10 \\
RNA & Traces \\
\hline
\end{tabular}

Table 2. Composition of the MFGM lipids. Data compiled from [7,9,10,25-27].

\begin{tabular}{|c|c|c|}
\hline Lipid Class & Fraction Content In \% & Subclass \\
\hline \multicolumn{3}{|c|}{ Polar Lipids } \\
\hline \multirow{10}{*}{ Phospholipids } & \multirow{10}{*}{65} & Glycerophospholipids \\
\hline & & $-\quad P E$ \\
\hline & & $-\quad P C$ \\
\hline & & - $\quad$ PS \\
\hline & & $-\quad P I$ \\
\hline & & Sphingolipids \\
\hline & & - $\quad$ Sphingomyelin (SM) ${ }^{a}$ \\
\hline & & - $\quad$ Glucosylceramide (GlcCer) ${ }^{b}$ \\
\hline & & - $\quad$ Galactoceramide (GalCer) ${ }^{b}$ \\
\hline & & - $\quad$ Lactosylceramide (LacCer) ${ }^{b}$ \\
\hline \multirow{9}{*}{$\begin{array}{l}\text { Gangliosides or } \\
\text { glycolipids }\end{array}$} & \multirow{9}{*}{5} & - $\quad$ Monosialoganglioside 1 (GM1) \\
\hline & & - $\quad$ Monosialoganglioside 2 (GM2) \\
\hline & & - $\quad$ Monosialoganglioside 3 (GM3) \\
\hline & & - $\quad$ Disialoganglioside 1A (GD1A) \\
\hline & & Disialoganglioside 1B (GD1B) \\
\hline & & - $\quad$ Disialoganglioside 2 (GD2) \\
\hline & & - $\quad$ Disialoganglioside 3 (GD3) \\
\hline & & Trisialoganglioside (GT) \\
\hline & & Trisialoganglioside 3 (GT3) \\
\hline
\end{tabular}

\begin{tabular}{|c|c|}
\hline \multicolumn{2}{|c|}{ Neutral Lipids } \\
\hline Di-acylglycerols & 10 \\
\hline Mono-acylglycerols & Traces \\
\hline Free fatty acids & 10 \\
\hline \multicolumn{2}{|c|}{ Sterols } \\
\hline Cholesterol & 10 \\
\hline \multicolumn{2}{|c|}{ Liposoluble molecules } \\
\hline Vitamins $A, D, E$ and $K$ & 5 \\
\hline
\end{tabular}

The MFGM possesses a rich variety of proteins as well, which are all membraneassociated and account for about $25 \%$ of the mass [34]. The protein profile is vast, and it varies between species. Human, bovine, and caprine MFGM possess 1104, 632, and 137 different proteins, respectively [35]. However, a group of eight proteins are usually the most abundant in all species. Figure 1B depicts this group of predominant MFGM proteins, as well as their locations in the different layers, and their orientation and association with phospholipids, carbohydrates, and other proteins. Table 3 summarizes their molecular size and, more importantly, their observed effects on human health. 

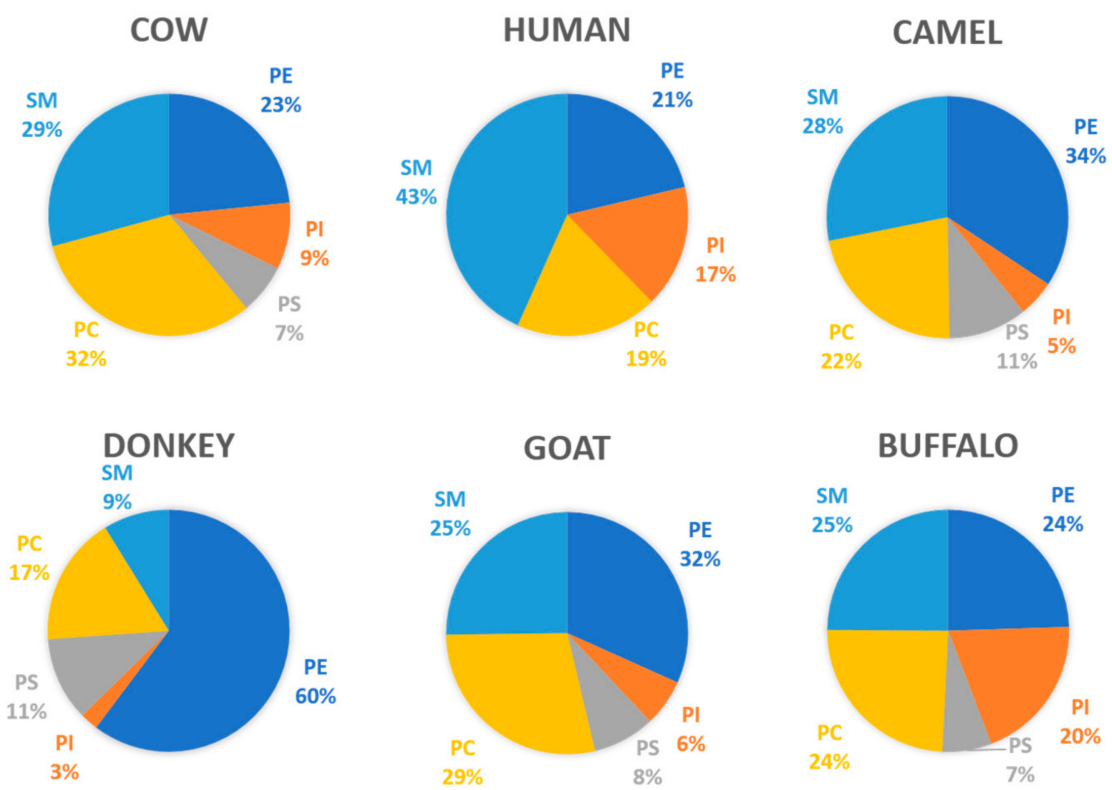

Figure 2. Variability of the milk phospholipid (MPL) profiles of different mammalian species. Data compiled from [28-33].

Table 3. Composition of the predominant MFGM proteins. Data compiled from [36-42].

\begin{tabular}{|c|c|c|c|}
\hline Protein & $\begin{array}{l}\text { Content in } \mathrm{g} / 100 \mathrm{~g} \text { of } \\
\text { Total Protein * }\end{array}$ & Molecular Mass (kDa) & $\begin{array}{l}\text { Reported Effect on } \\
\text { Human Health }\end{array}$ \\
\hline Mucin 1 (MUC-1) & NA & $250-450$ & $\begin{array}{l}\text { Antiviral and antibacterial by } \\
\text { preventing binding of pathogens } \\
\text { to intestinal cells }\end{array}$ \\
\hline Mucin 15 (MUC-15) & NA & $94-100$ & Antiviral action \\
\hline $\begin{array}{c}\text { Xanthine } \\
\text { dehydrogenase/oxidase } \\
(\mathrm{XDH} / \mathrm{XO})\end{array}$ & 0.58 & 150-155 & $\begin{array}{c}\text { Bactericidal action by production } \\
\text { of hydrogen peroxide and nitric } \\
\text { oxide }\end{array}$ \\
\hline $\begin{array}{l}\text { Cluster of differentiation } 36 \\
\text { (CD36) }\end{array}$ & 0.18 & $77-78$ & $\begin{array}{l}\text { Receptor for collagen and } \\
\text { thrombospondin. Scavenger } \\
\text { receptor for apoptotic cells }\end{array}$ \\
\hline Butyrophilin (BTN) & 3.35 & 66 & $\begin{array}{l}\text { Member of the immunoglobulin } \\
\text { superfamily, adhesive protein, } \\
\text { acts as a receptor and has a } \\
\text { positive effect in the immune } \\
\text { system. Co-inhibitor of T-cell } \\
\text { activation }\end{array}$ \\
\hline Adipophilin (ADPH) & 0.007 & 52 & $\begin{array}{l}\text { Facilitates transport of } \\
\text { triglycerides and fatty acids } \\
\text { during fat globule synthesis }\end{array}$ \\
\hline PAS $6 / 7$ or Lactadherin & 0.93 & $48-54$ & $\begin{array}{l}\text { Adhesive properties with effect in } \\
\text { the regulation of epithelial } \\
\text { coagulation. Role in synaptic } \\
\text { activity in the central nervous } \\
\text { system (CNS) and protection } \\
\text { against viral infection in the gut }\end{array}$ \\
\hline FABP family & 0.17 & $14-15$ & Transport of fatty acids \\
\hline
\end{tabular}


There is a lot to say about the MFGM proteins given their complex compositions. In addition to the predominant group shown in Table 3, hundreds of other proteins in minor concentrations are also found, and according to proteomic studies, we know that the distribution varies greatly upon the stage of lactation, environmental conditions, the method of extraction, and the processing of the source containing MFGM. These minor proteins have important functions in biological processes, such as antioxidant and detoxification properties, and molecular functions such as binding [35]. Finally, it is important to note that, according to the techniques used to isolate MFGM and process milk, whey proteins $(\alpha-$ lactalbumin, $\beta$-lactoglobulin, immunoglobulins, and lactoferrin) are often found associated with the MFGM fraction [34].

\subsection{Lactic Acid Bacteria (LAB) and Bifidobacteria}

With this review, we aim to showcase the interactions between the MFGM and probiotic bacteria, but first, we must highlight some of the notable features of these bacteria to better understand their behaviors in complex systems. The two major groups of probiotic bacteria are LAB and bifidobacteria. LAB are an important group of microorganisms of great relevance for the food, clinical, and agricultural industries. Their main application is in the preservation of foods by the production of lactic acid through fermentation. According to the current taxonomic classification, the LAB group belongs to the phylum Firmicutes, class Bacilli, and order Lactobacillales, which comprises six families: Aerococcaceae, Carnobacteriaceae, Enterococcaceae, Lactobacillaceae, Leuconostocaceae, and Streptococcaceae [43]. In general, LAB are Gram-positive, non-spore-forming, aerotolerant, acid tolerant, rod- or coccus-shaped bacteria that produce lactic acid and other organic compounds as a final product of carbohydrate catabolism, contributing to the taste, texture, and final aroma of foods that contain them [44]. These bacteria are usually nonmotile and present a complex, nutritionally fastidious requirement of vitamins, nutrients, and amino acids for growth. LAB are distributed in nature in nutrient-rich habitats, including niches such as food (dairy, fermented meat, cereals, fruits, and vegetables) and in human and animal cavities (mouth, genitals, respiratory, and intestinal tracts).

Although LAB are already a diverse group of bacteria, they are further diversified by containing circular and linear plasmids that give them the ability to survive in different environments and contain additional genes that alter their metabolism. These include genes for the metabolism of amino acids, citrate, carbohydrates, and proteins, as well as genes involved in the production of bacteriocins, exopolysaccharides (EPSs), and pigments; defense mechanisms against phages; and resistance to antibiotics and heavy metals [45]. LAB are classified based on their physiological and biochemical characteristics, such as their growth at different temperatures $\left(15-45^{\circ} \mathrm{C}\right)$, ability to grow in high salt concentrations $(6.5$ and $18 \%$ $\mathrm{NaCl})$, tolerance to alkali or ethanol, cell wall or fatty acid compositions, and capacity for acid production during carbohydrate fermentation. Based on their metabolic products, LAB can be classified as homofermentative (i.e., Lactococcus and Streptococcus) or heterofermentative (i.e., Leuconostoc, Wiessella, and some Lactobacillus), which produce two lactate molecules per glucose via the Embden-Meyerhof-Parnas pathway or lactate, ethanol, and carbon dioxide from glucose via the 6-P-gluconate/phosphoketolase pathway, respectively [46].

Another group of bacteria, called bifidobacteria, are commonly associated with LAB in fermented foods but are distinct in their physiological, biochemical, and metabolic characteristics. The genus Bifidobacterium belongs to the Bifidobacteriaceae family, order of Bifidobacteriales, and belong to a branch of the phylum Actinobacteria [47]. Currently, this genus contains 80 recognized taxa, 95 species, and 18 subspecies (https:/ / psn.dsmz.de/genus / bifidobacterium) divided into six phylogenetic groups: B. adolescentis, B. longum, B. pullorum, B. asteroides, B. pseudolongum, and B. boum [48]. Bifidobacteria are Gram-positive, non-sporeforming, nonmotile, mostly anaerobic, and generally rod- or bifid-shaped bacteria. Their optimal growth temperature ranges from 37 to $41^{\circ} \mathrm{C}$. These bacteria can produce acetic and lactic acids from the fermentation of glucose, galactose, and fructose without generating carbon dioxide. Unique to bifidobacteria, carbohydrate fermentation occurs through the 
fructose-6-phosphate phosphoketolase pathway, also called the Bifid shunt. It is through this pathway that bifidobacteria are well-recognized for their utilization of human milk oligosaccharides (HMOs) for growth and gut microbiome development in infants [49]. Their main niche is the intestinal tract and mouth of humans or animals, although they have also been isolated from birds and insects, sewage, fermented milk, and blood.

Bifidobacteria and some LAB are generally considered nonpathogenic and are commonly used as probiotics in fermented products and food supplements. Probiotics are defined as "living microorganisms that when administered in adequate proportions can confer benefits on the health of the host" [50]. However, the applications of bifidobacteria and $\mathrm{LAB}$ differ because of their differences in metabolism and physiology. For example, bifidobacteria have certain growth disadvantages in fermented products, including dairy products, compared to LAB. They grow and acidify poorly in cow's milk; have low proteolytic activity; and require longer fermentation periods, anaerobic conditions, and low redox potential to grow. Some of these challenges can be overcome through addition of substances such as ascorbic acid or cysteine to reduce the redox potential and promote growth [51]. In addition, some species can survive the acidic environment of the stomach and duodenum and the presence of bile salts and pancreatic juices, but these are very aggressive conditions for bifidobacteria, and their proportions diminish over time. LAB are commonly used as starter cultures for food fermentation due to the metabolites that they produce, such as lactic acid and proteins with antibacterial activity. They prevent the decomposition of food and the growth of pathogenic microorganisms.

Both LAB and bifidobacteria colonize the gastrointestinal tract of the host by adhering to intestinal cells, exhibiting a resistance to host barriers [52]. The adhesion of bacteria in the intestine is related to the presence of mucins whose functions are to lubricate and protect the epithelial cells, increasing the adherence of LAB and bifidobacteria while concurrently excluding pathogenic bacteria. Pathogen exclusion occurs through various mechanisms. For example, Lactobacillus can produce substances with antimicrobial activity with an inhibitory effect against pathogenic enteric bacteria [53]. LAB and bifidobacteria are essential for the health of the host by their direct involvement in metabolism, digestion, and preservation of the immune system [54]. Both LAB and bifidobacteria are found as part of the human milk microbiome. Although the exact composition of bacteria varies between mothers, the predominant species in breast milk include Ligilactobacillus salivarius, Limosilactobacillus fermentum, Lactobacillus gasseri, B. breve, B. adolescentis, and B. longum subsp. infantis [55]. $\mathrm{LAB}$, through delivery in infant formulas, have been shown to promote health through mitigation of several conditions in infants. For example, L. fermentum CECT5716 has been shown to reduce the risk and duration of diarrhea [56], Limosilactobacillus reuteri DSM17398 has been shown to aid in colic management [57], and Lacticaseibacillus paracasei CBA L74 is protective against colitis and pathogen infection [58]. In addition, bifidobacteria is one of the predominant groups associated with a healthy human microbiota. They rapidly colonize the intestine of infants and are transmitted directly from the mother to the infant to form part of their microbiota. Bifidobacteria found in infants modulate their metabolism toward degradation of oligosaccharides present in breast milk, while those found in adults mainly degrade complex carbohydrates from the diet, establishing an interaction between bifidobacteria and other microorganisms present in the gastrointestinal tract [47]. The predominant species in infants are B. breve, B. infantis, and B. longum, while B. catenulatum, B. longum, and B. adolescents are the species commonly found in the gastrointestinal tract (GIT) of adults [51]. Their presence has been attributed to the promotion of health benefits such as improving lactose digestibility, synthesis of vitamin B, facilitating calcium absorption, preventing diarrhea, reducing cholesterol levels, production of vitamins, immunostimulation, and anticarcinogenic effects [59].

\section{Interactions of Bifidobacteria, LAB, and MFGM in Dairy Food Matrixes}

Milk and dairy products are the most popular matrices for the dietary delivery of LAB and bifidobacteria to humans, but little is known about how the MFGM interacts 
with and impacts bacterial cells. Moreover, no mechanism has yet been fully described to explain this interaction. The knowledge of the latter could very well contribute to the development of more efficient dairy foods, with an increased impact on human health Since the middle of the last century, the inclusion of LAB in fermented foods has generated a revolution in the processing, production, and consumption of foods. Since that time, several starter cultures have been developed for fermentation and direct inoculation in food matrices. A starter culture is defined as a group of microorganisms that are inoculated directly into the food matrix with the intention of providing desirable changes in the final product [60]. One application of the interactions between LAB and MFGM is their utilization for the cryoprotection of stock and starter cultures. Bacterial freezing processes decrease the cell viability, damage the bacterial membrane, and reduce their functionality. The supplementation of $0.5 \%$ MPLs in acid whey-based media has been reported to protect LAB from freeze/thaw cycles [61]. Starter cultures also induce changes in a final product, including improved sensory and nutritional properties and compositional changes for the preservation of foods, as well as an added economic value [62]. The reactions amounting to these changes are directly related to the presence and composition of the carbohydrate, protein, and lipid components [63].

The interaction between MFGM and LAB and bifidobacteria is an adhesion phenomenon driven primarily by the bacterial surface properties. It is a very complex relationship that depends on many factors, including, but not limited to, strain genotype and phenotype and bacterial biochemistry, such as environmental conditions, cell viability, and metabolic activity. It is also impacted by the dairy matrix composition, water content, and processing strategies used upon the foods. Hence, there is no current set of rules or guidelines to predict whether the interaction will occur in all food matrices or under what mechanism; it should be reviewed case-by-case. In general, bacterial adhesion occurs in two steps: the first contact with the substrate is nonspecific and governed by reversible interactions such as electrostatic, van deer Waals, and Lewis acid-base. This step is followed by nonreversible and specific interactions involving adhesion factors, complementary receptors, surface appendages, teichoic and lipoteichoic acids, and EPSs from the cell envelope [64,65]. Given these phenomena, we should expect an attachment of $\mathrm{LAB}$ and bifidobacteria to the MFGM to occur in the same manner.

In dairy products, we now know that LAB and bifidobacteria are preferably associated with the fat/protein interfaces in cheeses at first, and after a period of aging, they have been found embedded in the MFGM or inside the fat globules when they exert their lipolytic activity [66-69]. Recently, a 45.9-kDa phosphoesterase with activity toward PL was isolated and characterized from Pediococcus acidilactici [70], which indicates a variety of lipolytic enzymes found in LAB and their affinity not only to milk fat but to MPL as well. Other research suggests that $\mathrm{LAB}$ and bifidobacteria may have additional activity beyond lipolysis of the MFGM components. For example, lactobacilli isolated from cheese has been shown to grow and utilize the monosaccharides present in MFGM glycoconjugates [71], which may alter the flavor development in cheeses [72].

In fresh cream, the direct association of LAB to fat droplets was informally reported in 2008 [73], and ever since, strains such as Lactococcus lactis ssp. lactis subv. Diacetylactis [74] and L. reuteri SD2112 and T1 have been shown to attach directly to the MFGM in the surface of fat globules (Figure 3). Moreover, Brisson and colleagues were able to establish that the mechanism of adhesion occurs through specific connections with the bacterial surface proteins [75].

Simple models have shown that many strains of LAB directly bind to MFGM components. Guerin and colleagues used atomic force microscopy to identify that Lacticaseibacillus rhamnosus GG (ATCC 53103) binds MFGM isolated from raw cream using functionalized probes, and moreover, they identified that the adhesion occurs through the interaction of SpaCBA pili in the bacterial cell wall [76]. 

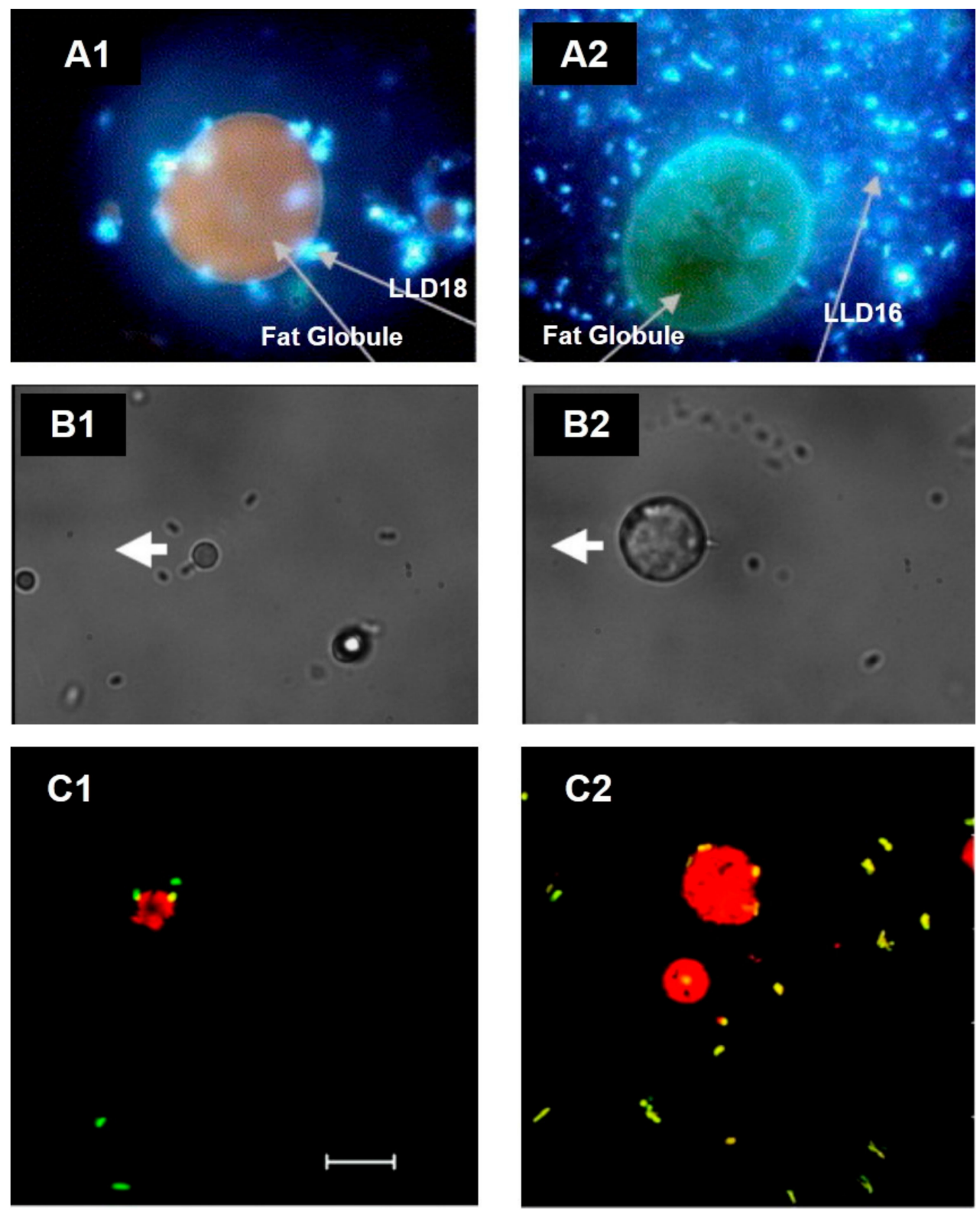

Figure 3. Association of lactic acid bacteria (LAB) with the MFGM in cream imaged by microscopy. (A) Fluorescence microscopy images of L. lactis ssp. lactis subv. Diacetylactis. (A1) Variant 18 (LLD18) is clearly attached to the MFGM, whereas (A2) variant 16 (LLD16), in comparison, is not. Adapted with permission from Ly et al. (2006) Copyright 2006 Elsevier Ltd. [74]. (B) Optical tweezer force images of L. reuteri SD2112 attached to the MFGM. (B1) Bacterial cells fixed to the cover slide, whereas (B2) shows the experiment when the MFGM is attached to the cover slide. The thick white arrow shows the direction of the microscope stage travel. Adapted with permission from Brisson et al. (2010). Copyright 2010 American Chemical Society [75]. (C) Confocal laser scanning images of (C1) L. reuteri SD2112 and (C2) L. reuteri $\mathrm{T}-1$ in raw cream. Scale bar $=10 \mu \mathrm{m}$. Adapted with permission from Brisson et al. (2010). Copyright 2010 American Chemical Society [75].

It is clear that many strains of LAB, in fact, interact with the MFGM; however, the identification of the specific components from the MFGM that interact with these bacteria are not well-known to date. We can hypothesize, based on the literature, that LAB are prone to bind primarily to glycans of the MFGM proteins, such as PAS6/7 and mucins, due to their high degree of glycosylation (approximately $10 \%$ and $60 \%$, respectively) [40,77-79]. MUC1 is resistant to gastrointestinal digestion, likely due to its sugar moieties, including 
fucose, galactose, mannose, $\mathrm{N}$-acetylgalactosamine, and $\mathrm{N}$-acetylglucosamine, among other sugars, which sterically protect it from proteolytic degradation $[79,80]$. PAS6/7 has been previously reported to retain its ability to bind bacteria due not only to its glycosylation but, also, its association with lipids and, specifically, PS [40,81]. A study used the sucrose density gradient to show that six strains of $L$. reuteri isolated from various dairy products bind MPLs from the MFGM [82]. L. reuteri showed greater interactions with MPLs compared to Pediococcus lolii, suggesting that these interactions can vary at the genus and species levels. In addition, it was found that some of the strains contained an increased relative expression of surface-binding promoting genes $C m b A, C n b$, and MapA with the addition of $1 \%(w / v)$ of MPL. Mucus adhesion-promoting protein (MapA), the collagen-binding protein $(\mathrm{Cnb})$, and a putative sortase-dependent cell and mucus binding protein $\mathrm{A}(\mathrm{CmbA})$ have been shown to promote the adhesion of bacteria to intestinal epithelial cells [83-86].

In our research group, through transmission electron microscopy (TEM), we identified that MPLs from the MFGM in simple models bind directly to the surface of some Lactobacillus (Figure $4(\mathrm{~A} 1, \mathrm{~B} 1))$ in a strain-dependent manner during cell growth rather than internalizing them for further metabolism. This, in turn, affects the parameters of the bacteria, such as the growth rate; cryotolerance; surface hydrophobicity; $\zeta$-potential; and adhesion properties such as expression of adhesion factors and mucus-binding proteins $[82,86,87]$ (Ortega-Anaya, J., Ohio State University, Columbus, OH, USA; personal communication, 2020). In complex matrices such as milk and dairy products, the interaction, as well as the outcome, is expected to be more complex.
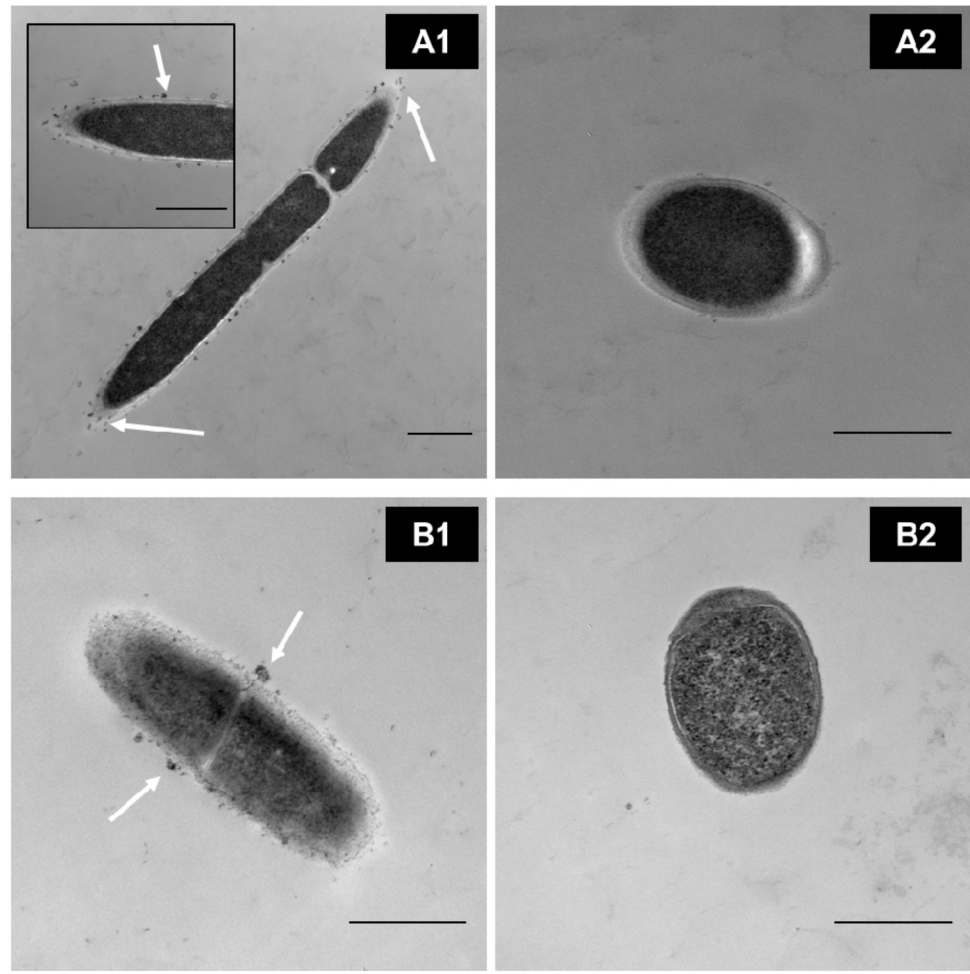

Figure 4. TEM images of washed cells grown in a defined medium supplemented with $0.5 \%$ of MPL. (A1) Lactobacillus delbrueckii vs. (A2) control. (B1) Lactiplantibacillus plantarum vs. (B2) its control. Scale bar $=500 \mathrm{~nm}$. White arrows indicate MPL accumulation at the cell surface(Unpublished images, Ortega-Anaya (2020) Ohio State University, Columbus, OH, USA; personal communication). 


\section{Evidence of Improved Health with Combined Probiotic and MFGM Supplementation}

Although the exact mechanism of interaction between probiotics and the MFGM has not been fully elucidated, the evidence of the synergistic effects upon the combined supplementation of these functional ingredients suggests beneficial outcomes in both in vitro and in vivo studies, including studies in infants (summarized in Table 4).

Table 4. Purported health benefits of combined probiotic and MFGM supplementation.

\begin{tabular}{|c|c|c|c|c|c|}
\hline Ingredient & Microorganism(s) & Model & Experimental Design & Key Findings & Ref. \\
\hline \multicolumn{6}{|c|}{ Bacterial Survival and Adhesion } \\
\hline $\begin{array}{l}\text { Whey-derived } \\
\text { MFGM (MFGM-10 } \\
\text { Lacprodan }^{\circledR} \text { ) }\end{array}$ & $\begin{array}{l}\text { L. rhamnosus GG } \\
\text { (LGG) }\end{array}$ & $\begin{array}{l}\text { Male, 6-week-old } \\
\text { BALB/c mice }\end{array}$ & $\begin{array}{l}\text { Oral gavage of } 0.1 \mathrm{~mL} \\
\text { MRSC media, MRSC } \\
\text { with } 5 \mathrm{~g} / \mathrm{L} \text { MFGM-10, } \\
\text { MRSC with LGG } \\
\left(5 \times 10^{7} \mathrm{CFU} / \mathrm{mL}\right) \text { or } \\
\text { MRSC with } 5 \mathrm{~g} / \mathrm{L} \\
\text { MFGM-10 and LGG } \\
\left(5 \times 10^{7} \mathrm{CFU} / \mathrm{mL}\right) \text { for } \\
3 \text { days }\end{array}$ & $\begin{array}{l}\text { - } 2.5 \mathrm{~g} / \mathrm{L} \text { MFGM-10 } \\
\text { improved the survival of } \\
\text { LGG in } 0.5 \% \text { bile in vitro } \\
\text { potentially through } \\
\text { modified EPS production } \\
\text { Increased LGG viability } \\
\text { after GI transit using } \\
\text { cecum and fecal counts } \\
\text { in mice }\end{array}$ & {$[87]$} \\
\hline $\begin{array}{l}\text { MFGM-derived MPL } \\
\text { concentrate }\end{array}$ & $\begin{array}{l}\text { Lacticaseibacillus casei } \\
\text { OSU-PECh-C; } \\
\text { Lactobacillus } \\
\text { acidophilus } \\
\text { Musallam2; } \\
\text { L. plantarum subsp. } \\
\text { plantarum TW14-1; } \\
\text { L. delbruekii } \\
\text { OSU-PECh-3 }\end{array}$ & $\begin{array}{l}\text { Gold (Au) Sensor; } \\
\text { Caco-2/HT29-MTX }\end{array}$ & $\begin{array}{l}\text { Examined the adhesion } \\
\text { phenomena of } 4 \text { strains in } \\
\text { the presence or absence } \\
\text { of } 0.5 \%(w / v) \text { MPL to A) } \\
\text { a gold sensor using a } \\
\text { Quartz Crystal } \\
\text { Micrograph with } \\
\text { Dissipation (QCM-D); B) } \\
\text { TEM; and C) intestinal } \\
\text { cell culture }\end{array}$ & $\begin{array}{l}\text { Binding properties } \\
\text { observed by QCM-D and } \\
\text { TEM suggest } \\
\text { strain-specific differences } \\
\text { in interactions with MPL } \\
\text { L. casei and L. delbruekii } \\
\text { exhibited greater } \\
\text { adhesion to intestinal } \\
\text { co-culture in the presence } \\
\text { of } 0.5 \% \mathrm{MPL}\end{array}$ & {$[88]$} \\
\hline
\end{tabular}

\begin{tabular}{ccc}
\hline & P. acidilactici & \\
OSU-PECh-L; $P$. & \\
acidilactici & \\
OSU-PECh-3A; & LAB strains grown with \\
& L. plantarum & or without $0.5 \%(w)$ \\
MFGM-derived MPL & OSU-PECh-BB, $L$. & MPL were characterized \\
concentrate & reuteri OSUPECh- $48 ;$ & by functional properties \\
& L. casei OSU-PECh-C, & Caco-2 \\
L. paracasei & & to fully differentiated \\
OSU-PECh-BA; & Caco-2 cells \\
L. paracasei & \\
OSU-PECh-3B & \\
\hline
\end{tabular}

- No change in autoaggregation or cell surface hydrophobicity in the presence of MPL

- 3 out of 7 strains showed increased adhesion to intestinal cells when grown in MPL

LGG was exposed to $5 \mathrm{mg} / \mathrm{mL}$ MFGM extract MFGM extract from L. rhamnosus GG (LGG) for $1 \mathrm{~h}$ and applied to intestinal cells $\left(1 \times 10^{9} \mathrm{CFU} / \mathrm{mL}\right)$
- $\quad$ Atomic force microscopy (AFM) demonstrated interactions between LGG and MFGM may be due to SpaCBA pili

- $\quad$ MFGM decreased LGG adhesion to intestinal epithelial cells

\begin{tabular}{cc}
\hline $\begin{array}{c}\text { MPL-rich milk } \\
\text { protein concentrate } \\
\text { (Lacprodan }{ }^{\circledR} \text { PL-20) }\end{array}$ & \\
\hline Whey-derived & B. longum subsp. \\
MFGM (MFGM-10 & infantis ATCC 15697 \\
Lacprodan $\left.{ }^{\circledR}\right)$ & \\
\hline Buttermilk & \\
fraction (BF) & \\
\hline
\end{tabular}

Exposed bifidobacteria to MFGM ingredients for $1 \mathrm{~h}$ and measured adherence of bacteria to fully confluent cells after $2 \mathrm{~h}$ incubation using plate count method
- $\quad$ PL-20 and BF decreased adhesion of ATCC 15697

- MFGM-10 did not alter adhesion of ATCC 15697 
Table 4. Cont.

\begin{tabular}{|c|c|c|c|c|}
\hline Ingredient & Microorganism(s) & Model & Experimental Design & Key Findings \\
\hline \multicolumn{5}{|c|}{ Nutrient Absorption, Mucosal Immunity, and Gut Barrier Function } \\
\hline $\begin{array}{l}\text { MFGM-derived MPL } \\
\text { concentrate }\end{array}$ & $\begin{array}{l}\text { L. delbruekii subsp. } \\
\text { bulgaricus 2038; } \\
\text { S. thermophilus } 1131\end{array}$ & $\begin{array}{c}\text { Male } \\
\text { Sprague-Dawley rats }\end{array}$ & $\begin{array}{l}\text { Orally supplemented rats } \\
\text { with SM, MPLs alone or } \\
\text { either of these in } \\
\text { fermented milk }\end{array}$ & $\begin{array}{l}\text { - Fermented milk } \\
\text { containing SM increased } \\
\text { serum ceramide levels } \\
\text { twofold unlike } \\
\text { standard milk } \\
\text { MPLs in fermented milk } \\
\text { also increased serum } \\
\text { ceramide levels } \\
\text { Unclear mechanism, but } \\
\text { effect was attributed to a } \\
\text { property of the } \\
\text { fermented milk }\end{array}$ \\
\hline
\end{tabular}

- $\quad$ No differences in weight gain or growth between formula groups

- Compared to standard formula, both MFGM and F19 formulas resulted in

Double-blind RCT for an infant formula

Whey-derived MFGM (MFGM-10 Lacprodan $^{\circledR}$ )

L. paracasei subsp. paracasei F19 (F19)
Infants (21-days4-months old) supplemented with

MFGM (5 g/L prepared

formula) or F19

$\left(1 \times 10^{8} \mathrm{CFU} / \mathrm{L}\right)$

Ref fewer incidences of fever and days of fever more similar to breast milk (pre-registered primary outcome)

- No differences in respiratory tract infections between formula groups or breast-fed infants (pre-registered primary outcome)

Used reporter cell line to measure NF- $\mathrm{kB}$ activation in response to BB-12 $\left(1 \times 10^{6}\right.$ or $1 \times 10^{7} \mathrm{CFU} / \mathrm{mL}$ ) and/or MFGM (50

Unspecified B. animalis subsp. MFGM fraction lactis BB-12 (BB-12)
HT-29Cl34 (NF-kB reporter cell line); 28-day-old mice $\mu \mathrm{g} / \mathrm{mL}$ or $100 \mu \mathrm{g} / \mathrm{mL}$

and LPS challenge

$(100 \mathrm{ng} / \mathrm{mL})$; For in vivo

mouse study,

administered BB-12

$\left(1 \times 10^{8} \mathrm{CFU} /\right.$ day $)$,

MFGM $(0.6 \mathrm{mg} / \mathrm{g}$ of body

weight/day), or both

BB-12 and MFGM orally

for 1 or 4 weeks
- $\quad$ BB-12 and MFGM treatment synergistically reduced LPS-provoked NF- $K B$ activation in IECs greater than $\mathrm{BB}-12$ or MFGM alone

- 4-week BB-12 and MFGM supplementation increased IgA-secreting mucosal B cell counts in Peyer's patches, which further persisted 84 days after supplementation ended

MFGM components

B. infantis IM1;

L. rhamnosus LCS-742 12-month-old infants
Double-blind RCT (COGNIS study) for a novel infant formula containing bioactive ingredients, including MFGM $[10 \%$ of total protein content $(w / w)]$ and probiotics
- Improved brain maturation via cortical visual evoked potentials of infants fed experimental formula compared to standard formula at 12-months of age (pre-registered primary outcome)

- Responses of experimental formula-fed infants were closer to those of breast-fed infants 
Table 4. Cont

\begin{tabular}{|c|c|c|c|c|c|}
\hline Ingredient & Microorganism(s) & Model & Experimental Design & Key Findings & Ref. \\
\hline MFGM components & $\begin{array}{c}\text { B. infantis IM1; } \\
\text { L. rhamnosus LCS-742 }\end{array}$ & 4-year-old infants & $\begin{array}{l}\text { Double-blind RCT } \\
\text { (COGNIS study) for a } \\
\text { novel infant formula } \\
\text { containing bioactive } \\
\text { ingredients, including } \\
\text { MFGM }[10 \% \text { of total } \\
\text { protein content }(\mathrm{w} / \mathrm{w})] \\
\text { and probiotics }\end{array}$ & $\begin{array}{l}\text { Experimental formula } \\
\text { improved language use } \\
\text { and oral spontaneous } \\
\text { expression at } 4 \text { years old } \\
\text { by measure of the } \\
\text { PLON-R test } \\
\text { (pre-registered primary } \\
\text { outcome) }\end{array}$ & [94] \\
\hline
\end{tabular}

\subsection{Bacterial Survival and Adhesion}

Survival through gastrointestinal transit is considered an optimal trait for probiotic efficacy and bioactivity; however, probiotics are challenged with, and must overcome, the harsh physical and chemical environments of the GIT [95]. Probiotic survival is dependent on a tolerance to acidic $\mathrm{pH}$ and bile salts, bile salt hydrolase activity in the GIT, and the duration of exposure to these stressors [96]. Among the strategies used to boost probiotic survival in the GIT is the combination of probiotics with other nutritional components, such as prebiotics [97], or the use of milk as a delivery vehicle [98]. One study examined the potential for MFGM-10, an ingredient derived from whey protein concentrate (Lacprodan MFGM-10, Arla Food Ingredients, Viby, Denmark), to enhance the survival of L. rhamnosus GG (LGG) [87]. As little as 2.5-g/L MFGM-10 significantly improved the survival of LGG to 30 -min exposure of $0.5 \%$ bile conditions. In contrast, non-MFGM enriched whey protein concentrate (WPC) was unable to protect LGG from bile stress, demonstrating that increased survival is due to a specific property of the MFGM. Autoclaving had no effect on the protective activity of MFGM, indicating that this property is not thermolabile under these conditions. They also measured the survivability of LGG by cecum and fecal counts in mice, confirming the protective activity of MFGM in vivo. Mechanistically, bile stress upregulated EPS production of the bacteria. In the presence of MFGM, EPS production was downregulated more similarly to control the bacteria that lacked exposure to bile. EPSs have been shown previously to increase biofilm formation, increase intestinal adhesion, and influence the tolerance of the host immune system, all of which are important characteristics of probiotic activity [87,99]. Another study examined the contribution of the Lactobacillus johnsonii FI9785 EPS to facilitate interactions with the host via adhesion, biofilm formation, and stress resistance. These authors found a correlation of decreased EPS production with increased adhesion to chicken gut explants and a greater susceptibility to stress by bile salts and antibiotics. Therefore, it is possible that there is a trade-off between adhesion and survival in the GIT. EPSs also play a role in immune tolerance toward commensal bacteria and protection from pathogens [100]. This immune tolerance may be a plausible reason for why the delivery of probiotics in dairy matrices has been so successful-aside from the fact that LAB are nutritionally fastidious. Taken together, these findings demonstrate the direct effect of MFGM on bacterial metabolism and gene expression, which further raises the questions: what constituents of the MFGM aid in the regulation of EPS production, and how do these changes in survival impact adhesion in the gut?

Adhesion is a prerequisite for colonization that has sparked both biophysical and in vitro biological investigations into the influence of MFGM or MPLs on probiotic adherence to intestinal mucus or cells, as measuring colonization in vivo is challenging. Using a quartz crystal microbalance with dissipation (QCM-D) to measure the binding kinetics of LAB grown in the presence of MFGM-derived MPLs, our group found that MPLs increased the affinity for certain LAB species, including Lacticaseibacillus casei OSU-PECh-C and Lactobacillus acidophilus Musallam 2 to a gold sensor that acts as a universal binding surface [101]. Other strains, including L. plantarum subsp. plantarum TW14-1 and L. delbrueckii OSU-PECh3 , exhibited weaker interactions with the sensor. Interestingly, when these bacteria were applied to the Caco-2/HT29-MTX coculture, L. delbruekii and L. casei displayed increased 
adhesion in the presence of MPLs, suggesting MPLs increase the affinity for intestinal cells in a strain-dependent manner in vitro [88]. Using more traditional culture methods, Rocha-Mendoza et al. [86] found that $0.5 \%$ MPLs significantly increased the adhesion of $P$. acidilactici OSU-PECh-L, L. plantarum OSU-PECh-BB, and L. reuteri OSU-PECh-48 to in vitro Caco-2 cells, but MPLs had no significant change on the adhesion of the four other strains tested. In contrast, the MFGM extract derived from butter serum significantly reduced the number of adherent bacterial cells of the commercial probiotic LGG to Caco-2 TC7 cells [76]. Furthermore, high-throughput assays used to assess the effects of several dairy fractions on the adhesion of B. longum subsp. infantis ATCC 15697 to HT-29 cells showed that Lacprodan PL-20 (an MPL-rich ingredient from Arla Food Ingredients) and the buttermilk fraction significantly reduced the bacterial adhesion. MFGM did not alter the bacterial adhesion. These authors did not, however, report whether they used a mucus-producing clone of HT-29 cells, such as HT29-MTX-E12. As the mucus layer in the GIT serves as the key site of interaction between the host and microorganisms, it is necessary to conduct further research that includes this important structure to better understand the relationships between MFGM, probiotic survival, and adhesion.

With these ideas in mind, the next generation of studies must address whether the combination of MFGM and probiotics are capable of influencing colonization in vivo. However, these studies must additionally overcome the challenges associated with these measurements, as the fecal microbiome is not well-representative of the colonized microbiome in the GIT [102], and differences in microbiomes between species are not easily translatable [103]. Furthermore, Zmora et al. [102] reported that the colonization of probiotics in the GIT of adult humans is limited by individual host colonization resistances resulting from the resident microbiome, as the degree of probiotic enrichment varied between significantly between individuals.

\subsection{Nutrient Absorption, Mucosal Immunity, and Gut Barrier Function}

The mucosal immune system orchestrates the body's ability to absorb nutrients and tolerate commensal bacteria while simultaneously providing protection from pathogens by initiating (and later resolving) an immune response. Components such as the gut-associated lymphoid tissues (GALT), Peyer's patches, mucosal immune cells, and commensal bacteria work together to produce antimicrobial peptides, cytokines, and chemokines that maintain the gut homeostasis [104]. It has been reported that a milk fermentation containing SM and two LAB (L. delbrueckii subsp. bulgaricus 2038 and Streptococcus thermophilus 1131) increases the absorption of this phospholipid in murine models [90]. As previously discussed, SM is regarded for its function in regulating inflammation [105], promoting neurodevelopment and cognitive function [106,107], and improving the skin barrier function [108], among others.

It is well-documented that dietary composition and, specifically, milk components can directly influence the ability of the mucosal immune system to act in an appropriate and efficient manner and influence the proper development in infants [109,110]. A formula containing milk fat stabilized by MFGM fragments improved the markers for mucosal immune development, including IFN $\gamma$ secretion and intestinal microbiota composition in neonatal piglets [109]. Specifically, the formula led to an increase in Proteobacteria and Bacteroides and decrease in Firmicutes compared to a formula containing vegetable fat stabilized by a mixture of proteins. Although the microbial composition changes in piglets do not translate well to infants, the authors did observe a similar increase in Parabacteroides, which is a characteristic of breastfed infants [103]. Others have also shown that MFGM in infant formula can modify the fecal microbiota and metabolism of infants through changes in serum metabolites [111,112]. These data and others (reviewed in [34]) suggest that, individually, MFGM plays an important role in mucosal immunity. However, a co-supplementation with probiotics is purported to have greater synergistic effects on the mucosal immunity [92,113].

Specifically, one patent (WO2004/112509A2) describes an infant formula containing MFGM and, at minimum, one probiotic bacterial strain that acts synergistically to drive 
gut barrier maturation more closely to that of breast milk-fed infants [113]. These probiotic strains include Bifidobacterium adolescentis CNCM I-2168 (Bad4), B. longum CNCM I-2169 (B128), B. longum CNCM I-2170 (Bl29), L. paracasei ST11, Streptococcus thermophilus TH4, B. animalis subsp. lactis BB-12 (BB-12; ATCC27536), and B. longum BB536. The authors proposed the use of a probiotic cocktail in combination with MFGM or other bioactive components (i.e., human milk oligosaccharides, gangliosides, and sweet or acid whey), as each microorganism has differences in survival throughout the GIT. Another patent (WO2011/069987) embodies an infant formula that contains MFGM and probiotics that can be used as a therapeutic for disease prevention and to help drive normal gut development in infants [92]. The invention shows interactions between the MFGM and the commercial probiotic $B$. animalis subsp. lactis BB-12 (BB-12), which may help protect the probiotic during transit to the gut, where they can then modulate the immune system. Using an NF$\kappa B$ reporter epithelial cell line, the combination of MFGM and BB-12 showed a synergistic effect on NF- $\mathrm{KB}$ activation in response to the challenge with an endotoxin. The combination decreased NF- $\mathrm{KB}$ activation to a greater extent than MFGM or BB-12 alone. In addition, four weeks of combined MFGM and BB-12 consumption led to significantly higher IgA-secreting mucosal B cells in mice compared to BB-12 or MFGM alone. Secretory IgA produced by these cells has been well-studied for its role in mediating a tolerance to commensal gut microbes [114]. Together, these data show enhanced immune maturation and education and reduced inflammation when supplementations with MFGM and BB-12 are combined. Combined supplementation may offer benefits for developing infants, as well as for the prevention and treatment of gut-related diseases.

\subsection{Neurodevelopment and Cognitive Function}

During postnatal life, the brain rapidly undergoes changes in size, reaching $64 \%$ of its adult size within the first three months of life [115], as well as vast changes in neural networks stemming from increased exposure to enriched environments and experiences [116]. It is well-documented that nutrition and diet can also influence neurodevelopment in the postnatal period $[106,117,118]$. Moreover, MFGM and MFGM-derived MPLs alone have strong supporting evidence of the positive effects on cognitive function and brain development $[1,119,120]$. For example, an infant formula containing MFGM improved the reflex development and altered the brain lipid composition in rats with a pup-in-a-cup model more similarly to mother's milk [121]. MFGM in formula has also been reported to improve T-Maze scores in growth-restricted rats [122], improve stress-induced disruptions in rapid eye movement (REM) sleep [123], and improve infant scores using the Bayles Scale of Infant Development [124]. Combining MFGM with other bioactive ingredients, such as probiotics, may provide additional benefits throughout development, although the mechanisms have not yet been fully elucidated.

As part of a larger study called COGNIS, the effects of a functional infant formula containing MFGM components, symbiotics (a combination of prebiotics and probiotics), and other bioactive components on visual function as a measure of neurodevelopment was evaluated in infants [93]. The authors found that infants fed the functional formula had similar response rates to the breastfed group by the measure of cortical visual-evoked potentials at 12 months of age. The standard formula-fed infants had a significantly lower proportion of responses, suggesting that supplementation with these bioactive ingredients within the first year of life may promote neurodevelopment more similarly to breastfed infants. Ultimately, these results are promising for the combined supplementation of these bioactive ingredients; however, it is still necessary to better define which bioactive attributes are leading to these effects, as the functional formula contained other ingredients, such as prebiotics (fructooligosaccharides and inulin), as well long-chain polyunsaturated fatty acids (LC-PUFA). Another part of the COGNIS study investigated the effects of the same functional infant formula on long-term language development at four years of life [94]. The Oral Language Task of the Navarra-Revised (PLON-R) test was used to measure language development by categorizing kids into one of three categories: delayed, need to 
improve, or normal. The standard formula group was significantly more likely to fall into the delayed or need to improve categories than either the breastfed or functional formula groups. Additionally, the functional formula group showed significantly higher language use and oral spontaneous expression compared to the standard formula group. These data suggest that infant diets affect the long-term cognitive activity with respect to language development and that the diet containing both MFGM and probiotics narrowed the gap between formula-fed and breastfed infants.

\section{Current Applications and Future Perspectives}

The majority of research investigating the relationships between MFGM and probiotics occur in the area of infant formulas. MFGM research has long focused on the health benefits it provides, so logically, the idea of co-supplementations can be easily transitioned to this area. In infants, brain development and gut microbiota maturation are synchronized [125]. Although it appears that the co-consumption of MFGM and probiotics may hold additional developmental advantages, it is of great importance to better understand how this connection intertwines with the gut-brain axis, which has been shown to influence emotional, mental, and developmental health [126]. For example, the MFGM may influence not only the microbiota composition but, also, the metabolite production of the probiotics and resident gut microbiota-in turn, affecting the gut-brain axis [127]. Along with these ideas, we believe research in this area is important, as we have been left with several unanswered questions. At this point, it is still unclear whether the MFGM interaction with the bacterial surface facilitates the delivery of these probiotics to their target site of action or whether the MFGM creates an environment in the GIT that favors the probiotic species, alters their metabolism, and, ultimately, influences the gut microbiome. Relatedly, studies that further investigate the effects of MFGM or MPLs on bacterial surface biomolecules, such as EPSs and/or pili, in a variety of strains should be considered to uncover the mechanisms and, perhaps, the improvement of probiotic permanence in the GIT. As MFGM research continues to expand to other areas, including metabolic diseases [128], geriatrics and aging populations [129], and skin health [108], it would be no surprise to branch into these other areas as well.

In this review, we addressed the unique and complex composition of the MFGM, including the presence of phospholipids and sphingolipids. LAB isolated from dairy products have been shown to produce lipases, esterases, and phospholipases [130]. The lipolytic system from LAB is considered weak in comparison to their proteolytic processes. Yet, there have been several reports of the production of lipases by LAB $[70,131,132]$. Moreover, in matured products, such as aged cheeses, LAB release intracellular lipases after cell disruption. In addition to the lack of detailed, mechanistic evidence of lipolytic activity at the MFGM, there is an urgent need for expanding our understanding of the probiotic activity on other components such as MFGM glycoconjugates and proteins. Through this improved understanding, we can expand the flavor profiles of fermented foods, find novel bioactive metabolites to benefit human health, and use these concepts to create novel functional foods.

\section{Conclusions}

The advancement of human health through a co-supplementation of MFGM and probiotics holds significant promise and calls for the further exploration of potential synergies and interplaying mechanisms. The current evidence supports a functional role of the MFGM to probiotic bacteria like that of prebiotics. However, the exact mechanism of interaction between probiotics and the MFGM has yet to be fully elucidated. It is becoming increasingly evident that the MFGM may alter the metabolism of probiotics to enhance their efficacy in the gut by promoting probiotic survival, boosting mucosal immune development, and acting upon the gut-brain axis for improved cognitive function. These studies warrant further investigation into the other related aspects of gut health, 
such as the influence of the combined supplementation of MFGM and probiotics on the gut microbiota and more.

Author Contributions: Conceptualization, E.K. and I.G.-C.; writing-original draft preparation, E.K., D.R.-M., J.O.-A., R.J.-F. and I.G.-C.; writing-review and editing, E.K., R.J.-F., D.R.-M., J.O.-A. and I.G.-C.; visualization, J.O.-A.; and funding acquisition, R.J.-F. All authors have read and agreed to the published version of the manuscript.

Funding: This research received no external funding.

Institutional Review Board Statement: Not applicable.

Informed Consent Statement: Not applicable.

Data Availability Statement: Not applicable.

Acknowledgments: The authors thank Molly J. Davis for editing the manuscript.

Conflicts of Interest: The authors declare no conflict of interest.

\section{References}

1. Anto, L.; Warykas, S.W.; Torres-Gonzalez, M.; Blesso, C.N. Milk Polar Lipids: Underappreciated Lipids with Emerging Health Benefits. Nutrients 2020, 12, 1001. [CrossRef] [PubMed]

2. Snow, D.R.; Ward, R.E.; Olsen, A.; Jimenez-Flores, R.; Hintze, K.J. Membrane-Rich Milk Fat Diet Provides Protection against Gastrointestinal Leakiness in Mice Treated with Lipopolysaccharide. J. Dairy Sci. 2011, 94, 2201-2212. [CrossRef] [PubMed]

3. Fontecha, J.; Brink, L.; Wu, S.; Pouliot, Y.; Visioli, F.; Jiménez-Flores, R. Sources, Production, and Clinical Treatments of Milk Fat Globule Membrane for Infant Nutrition and Well-Being. Nutrients 2020, 12, 25. [CrossRef] [PubMed]

4. Heid, H.W.; Keenan, T.W. Intracellular Origin and Secretion of Milk Fat Globules. Eur. J. Cell Biol. 2005, 84, 245-258. [CrossRef]

5. Keenan, T.W.; Mather, I.H. Intracellular Origin of Milk Fat Globules and Nature of the Milk Fat Globule Membrane. In Advanced Dairy Chemistry Volume 2 Lipids; Springer: Boston, MA, USA, 2006; pp. 137-171. ISBN 978-0-387-28813-0.

6. Silanikove, N.; Shapiro, F. Distribution of Xanthine Oxidase and Xanthine Dehydrogenase Activity in Bovine Milk: Physiological and Technological Implications. Int. Dairy J. 2007, 17, 1188-1194. [CrossRef]

7. Ortega-Anaya, J.; Marciniak, A.; Jiménez-Flores, R. Milk Lipids I Milk Fat Globule Membrane. In Reference Module in Food Science; Elsevier: Amsterdam, The Netherlands, 2020; ISBN 978-0-08-100596-5.

8. McManaman, J.L.; Palmer, C.A.; Wright, R.M.; Neville, M.C. Functional Regulation of Xanthine Oxidoreductase Expression and Localization in the Mouse Mammary Gland: Evidence of a Role in Lipid Secretion. J. Physiol. 2002, 545, 567-579. [CrossRef]

9. Gallier, S.; Laubscher, A.; Jiménez-Flores, R. The milk fat globule membrane. In Food Structures, Digestion and Health; Elsevier: Amsterdam, The Netherlands, 2014; pp. 107-142. ISBN 978-0-12-404610-8.

10. Ortega-Anaya, J.; Jiménez-Flores, R. Symposium Review: The Relevance of Bovine Milk Phospholipids in Human NutritionEvidence of the Effect on Infant Gut and Brain Development. J. Dairy Sci. 2019, 102, 2738-2748. [CrossRef]

11. Martel, M.B.; Dubois, P.; Got, R. Human milk fat globule membranes. Preparation, morphological studies and chemical composition. Biochim. Biophys. Acta 1973, 311, 565-575. [CrossRef]

12. Patton, S.; Keenan, T.W. The Milk Fat Globule Membrane. Biochim. Biophys. Acta 1975, 415, 27309. [CrossRef]

13. Fong, B.Y.; Norris, C.S.; MacGibbon, A.K.H. Protein and Lipid Composition of Bovine Milk-Fat-Globule Membrane. Int. Dairy J. 2007, 17, 275-288. [CrossRef]

14. Sánchez-Juanes, F.; Alonso, J.M.; Zancada, L.; Hueso, P. Distribution and Fatty Acid Content of Phospholipids from Bovine Milk and Bovine Milk Fat Globule Membranes. Int. Dairy J. 2009, 19, 273-278. [CrossRef]

15. Dewettinck, K.; Rombaut, R.; Thienpont, N.; Le, T.T.; Messens, K.; Van Camp, J. Nutritional and Technological Aspects of Milk Fat Globule Membrane Material. Int. Dairy J. 2008, 18, 436-457. [CrossRef]

16. Jiménez-Flores, R.; Higuera-Ciapara, I.; Pouliot, Y. Beverages based on milk fat globule membrane (MFGM) and other novel concepts for dairy-based functional beverages. In Functional and Speciality Beverage Technology; Paquin, P., Ed.; Woodhead Publishing: Sawston, UK, 2009; pp. 281-296. ISBN 978-1-84569-342-8.

17. Deeth, H.C. The Role of Phospholipids in the Stability of Milk Fat Globules. Aust. J. Dairy Technol. 1997, 52.

18. Bourlieu, C.; Bouzerzour, K.; Ferret-Bernard, S.; Bourgot, C.L.; Chever, S.; Ménard, O.; Deglaire, A.; Cuinet, I.; Ruyet, P.L.; Bonhomme, C.; et al. Infant Formula Interface and Fat Source Impact on Neonatal Digestion and Gut Microbiota: Infant Formula Structure Affects Neonatal Health. Eur. J. Lipid Sci. Technol. 2015, 117, 1500-1512. [CrossRef]

19. Claumarchirant, L.; Cilla, A.; Matencio, E.; Sanchez-Siles, L.M.; Castro-Gomez, P.; Fontecha, J.; Alegría, A.; Lagarda, M.J. Addition of Milk Fat Globule Membrane as an Ingredient of Infant Formulas for Resembling the Polar Lipids of Human Milk. Int. Dairy J. 2016, 61, 228-238. [CrossRef]

20. Murthy, A.V.R.; Guyomarc'h, F.; Lopez, C. Cholesterol Decreases the Size and the Mechanical Resistance to Rupture of Sphingomyelin Rich Domains in Lipid Bilayers Studied as a Model of the Milk Fat Globule Membrane. Langmuir 2016, 32, 6757-6765. [CrossRef] [PubMed] 
21. Lopez, C.; Madec, M.-N.; Jimenez-Flores, R. Lipid Rafts in the Bovine Milk Fat Globule Membrane Revealed by the Lateral Segregation of Phospholipids and Heterogeneous Distribution of Glycoproteins. Food Chem. 2010, 120, 22-33. [CrossRef]

22. Guyomarc'h, F.; Zou, S.; Chen, M.; Milhiet, P.-E.; Godefroy, C.; Vié, V.; Lopez, C. Milk Sphingomyelin Domains in Biomimetic Membranes and the Role of Cholesterol: Morphology and Nanomechanical Properties Investigated Using AFM and Force Spectroscopy. Langmuir 2014, 30, 6516-6524. [CrossRef]

23. Guyomarc'h, F.; Chen, M.; Et-Thakafy, O.; Zou, S.; Lopez, C. Gel-Gel Phase Separation within Milk Sphingomyelin Domains Revealed at the Nanoscale Using Atomic Force Microscopy. Biochim. Biophys. Acta 2017, 1859, 949-958. [CrossRef]

24. Georgi, G.; Bartke, N.; Wiens, F.; Stahl, B. Functional Glycans and Glycoconjugates in Human Milk. Am. J. Clin. Nutr. 2013, 98, 578S-585S. [CrossRef]

25. Iwamori, M.; Takamizawa, K.; Momoeda, M.; Iwamori, Y.; Taketani, Y. Gangliosides in Human, Cow and Goat Milk, and Their Abilities as to Neutralization of Cholera Toxin and Botulinum Type A Neurotoxin. Glycoconj. J. 2008, 25, 675-683. [CrossRef] [PubMed]

26. Ross, S.A.; Lane, J.A.; Kilcoyne, M.; Joshi, L.; Hickey, R.M. Defatted Bovine Milk Fat Globule Membrane Inhibits Association of Enterohaemorrhagic Escherichia Coli O157:H7 with Human HT-29 Cells. Int. Dairy J. 2016, 59, 36-43. [CrossRef]

27. Lopez, C.; Cauty, C.; Guyomarc'h, F. Unraveling the Complexity of Milk Fat Globules to Tailor Bioinspired Emulsions Providing Health Benefits: The Key Role Played by the Biological Membrane. Eur. J. Lipid Sci. Tech. 2019, 121, 1800201. [CrossRef]

28. Andreotti, G.; Trivellone, E.; Motta, A. Characterization of Buffalo Milk by 31P-Nuclear Magnetic Resonance Spectroscopy. J. Food Compost. Anal. 2006, 19, 843-849. [CrossRef]

29. Lamothe, S.; Robitaille, G.; St-Gelais, D.; Britten, M. Butter Making from Caprine Creams: Effect of Washing Treatment on Phospholipids and Milk Fat Globule Membrane Proteins Distribution. J. Dairy Res. 2008, 75, 439-443. [CrossRef] [PubMed]

30. Rodríguez-Alcalá, L.M.; Fontecha, J. Major Lipid Classes Separation of Buttermilk, and Cows, Goats and Ewes Milk by High Performance Liquid Chromatography with an Evaporative Light Scattering Detector Focused on the Phospholipid Fraction. J. Chromatogr. A 2010, 1217, 3063-3066. [CrossRef] [PubMed]

31. Donato, P.; Cacciola, F.; Cichello, F.; Russo, M.; Dugo, P.; Mondello, L. Determination of Phospholipids in Milk Samples by Means of Hydrophilic Interaction Liquid Chromatography Coupled to Evaporative Light Scattering and Mass Spectrometry Detection. J. Chromatogr. A 2011, 1218, 6476-6482. [CrossRef]

32. Contarini, G.; Povolo, M. Phospholipids in Milk Fat: Composition, Biological and Technological Significance, and Analytical Strategies. Int. J. Mol. Sci. 2013, 14, 2808-2831. [CrossRef]

33. Pimentel, L.; Gomes, A.; Pintado, M.; Rodríguez-Alcalá, L.M. Isolation and Analysis of Phospholipids in Dairy Foods. J. Anal. Methods Chem. 2016, 2016, 1-12. [CrossRef]

34. Lee, H.; Padhi, E.; Hasegawa, Y.; Larke, J.; Parenti, M.; Wang, A.; Hernell, O.; Lönnerdal, B.; Slupsky, C. Compositional Dynamics of the Milk Fat Globule and Its Role in Infant Development. Front. Pediatr. 2018, 6. [CrossRef]

35. Ma, Y.; Zhang, L.; Wu, Y.; Zhou, P. Changes in Milk Fat Globule Membrane Proteome after Pasteurization in Human, Bovine and Caprine Species. Food Chem. 2019, 279, 209-215. [CrossRef]

36. Riccio, P. The Proteins of the Milk Fat Globule Membrane in the Balance. Trends Food Sci. Technol. 2004, 15, 458-461. [CrossRef]

37. Michalski, M.-C.; Januel, C. Does Homogenization Affect the Human Health Properties of Cow's Milk? Trends Food Sci. Technol. 2006, 17, 423-437. [CrossRef]

38. Pan, Y.; Lee, A.; Wan, J.; Coventry, M.J.; Michalski, W.P.; Shiell, B.; Roginski, H. Antiviral Properties of Milk Proteins and Peptides. Int. Dairy J. 2006, 16, 1252-1261. [CrossRef]

39. Ross, S.A.; Lane, J.; Kilcoyne, M.; Joshi, L.; Hickey, R.M. The milk fat globule membrane: A potential source of health-promoting glycans. In Biotechnology of Bioactive Compounds; John Wiley \& Sons, Ltd.: Hoboken, NJ, USA, 2015; pp. 631-668. ISBN 978-1-11873310-3.

40. Kamińska, A.; Enguita, F.J.; Stępień, E.Ł. Lactadherin: An Unappreciated Haemostasis Regulator and Potential Therapeutic Agent. Vascul. Pharmacol. 2018, 101, 21-28. [CrossRef] [PubMed]

41. Parrón, J.A.; Ripollés, D.; Sánchez, A.C.; Pérez, M.D.; Calvo, M.; López, S.; Arias, C.F.; Sánchez, L. Antirotaviral Activity of Bovine Milk Components: Extending the List of Inhibitory Proteins and Seeking a Better Understanding of Their Neutralization Mechanism. J. Funct. Foods 2018, 44, 103-111. [CrossRef]

42. Bär, C.; Mathis, D.; Neuhaus, P.; Dürr, D.; Bisig, W.; Egger, L.; Portmann, R. Protein Profile of Dairy Products: Simultaneous Quantification of Twenty Bovine Milk Proteins. Int. Dairy J. 2019, 97, 167-175. [CrossRef]

43. Boone, D.R.; Castenholz, R.W.; Garrity, G.M. (Eds.) Bergey's Manual of Systematic Bacteriology, 2nd ed.; Springer: New York, NY, USA, 2001; Volume 3, ISBN 978-0-387-98771-2.

44. Bintsis, T. Lactic Acid Bacteria as Starter Cultures: An Update in Their Metabolism and Genetics. AIMS Microbiol. 2018, 4, 665-684. [CrossRef]

45. Cui, Y.; Hu, T.; Qu, X.; Zhang, L.; Ding, Z.; Dong, A. Plasmids from Food Lactic Acid Bacteria: Diversity, Similarity, and New Developments. Int. J. Mol. Sci. 2015, 16, 13172-13202. [CrossRef]

46. Gaspar, P.; Carvalho, A.L.; Vinga, S.; Santos, H.; Neves, A.R. From Physiology to Systems Metabolic Engineering for the Production of Biochemicals by Lactic Acid Bacteria. Biotechnol. Adv. 2013, 31, 764-788. [CrossRef]

47. Bondue, P.; Delcenserie, V. Genome of Bifidobacteria and Carbohydrate Metabolism. Korean J. Food Sci. Anim. Resour. 2015, 35, 1-9. [CrossRef] 
48. Felis, G.E.; Dellaglio, F. Taxonomy of Lactobacilli and Bifidobacteria. Curr. Issues Intest. Microbiol. 2007, 8, 44-61. [PubMed]

49. Katayama, T. Host-Derived Glycans Serve as Selected Nutrients for the Gut Microbe: Human Milk Oligosaccharides and Bifidobacteria. Biosci. Biotechnol. Biochem. 2016, 80, 621-632. [CrossRef] [PubMed]

50. Hill, C.; Guarner, F.; Reid, G.; Gibson, G.R.; Merenstein, D.J.; Pot, B.; Morelli, L.; Canani, R.B.; Flint, H.J.; Salminen, S.; et al. The International Scientific Association for Probiotics and Prebiotics Consensus Statement on the Scope and Appropriate Use of the Term Probiotic. Nat. Rev. Gasterol. Hepatol. 2014, 11, 506-514. [CrossRef] [PubMed]

51. Prasanna, P.H.P.; Grandison, A.S.; Charalampopoulos, D. Bifidobacteria in Milk Products: An Overview of Physiological and Biochemical Properties, Exopolysaccharide Production, Selection Criteria of Milk Products and Health Benefits. Food Res. Int. 2014, 55, 247-262. [CrossRef]

52. Lebeer, S.; Vanderleyden, J.; De Keersmaecker, S.C.J. Genes and Molecules of Lactobacilli Supporting Probiotic Action. Microbiol. Mol. Biol. Rev. 2008, 72, 728-764. [CrossRef]

53. Dupont, A.; Heinbockel, L.; Brandenburg, K.; Hornef, M.W. Antimicrobial Peptides and the Enteric Mucus Layer Act in Concert to Protect the Intestinal Mucosa. Gut Microbes 2014, 5, 761-765. [CrossRef]

54. Tavares, L.M.; de Jesus, L.C.L.; da Silva, T.F.; Barroso, F.A.L.; Batista, V.L.; Coelho-Rocha, N.D.; Azevedo, V.; Drumond, M.M.; Mancha-Agresti, P. Novel Strategies for Efficient Production and Delivery of Live Biotherapeutics and Biotechnological Uses of Lactococcus Lactis: The Lactic Acid Bacterium Model. Front. Bioeng. Biotechnol. 2020, 8, 517166. [CrossRef] [PubMed]

55. Ruiz, L.; García-Carral, C.; Rodriguez, J.M. Unfolding the Human Milk Microbiome Landscape in the Omics Era. Front. Microbiol. 2019, 10, 1378. [CrossRef]

56. Maldonado, J.; Gil-Campos, M.; Maldonado-Lobón, J.A.; Benavides, M.R.; Flores-Rojas, K.; Jaldo, R.; Jiménez del Barco, I.; Bolívar, V.; Valero, A.D.; Prados, E.; et al. Evaluation of the Safety, Tolerance and Efficacy of 1-Year Consumption of Infant Formula Supplemented with Lactobacillus fermentum CECT5716 Lc40 or Bifidobacterium breve CECT7263: A Randomized Controlled Trial. BMC Pediatr. 2019, 19, 361. [CrossRef] [PubMed]

57. Sung, V.; D'Amico, F.; Cabana, M.D.; Chau, K.; Koren, G.; Savino, F.; Szajewska, H.; Deshpande, G.; Dupont, C.; Indrio, F.; et al. Lactobacillus reuteri to Treat Infant Colic: A Meta-Analysis. Pediatrics 2018, 141, e20171811. [CrossRef] [PubMed]

58. Zagato, E.; Mileti, E.; Massimiliano, L.; Fasano, F.; Budelli, A.; Penna, G.; Rescigno, M. Lactobacillus Paracasei CBA L74 Metabolic Products and Fermented Milk for Infant Formula Have Anti-Inflammatory Activity on Dendritic Cells In Vitro and Protective Effects against Colitis and an Enteric Pathogen In Vivo. PLoS ONE 2014, 9, e87615. [CrossRef] [PubMed]

59. O'Callaghan, A.; van Sinderen, D. Bifidobacteria and Their Role as Members of the Human Gut Microbiota. Front. Microbiol. 2016, 7. [CrossRef]

60. Durso, L.; Hutkins, R. Starter Cultures. In Encyclopedia of Food Sciences and Nutrition; Caballero, B., Ed.; Academic Press: Oxford, UK, 2003; pp. 5583-5593. ISBN 978-0-12-227055-0.

61. Zhang, L.; García-Cano, I.; Jiménez-Flores, R. Effect of Milk Phospholipids on the Growth and Cryotolerance of Lactic Acid Bacteria Cultured and Stored in Acid Whey-Based Media. JDS Commun. 2020, S2666910220300351. [CrossRef]

62. McSweeney, P.L.H.; Sousa, M.J. Biochemical Pathways for the Production of Flavour Compounds in Cheeses during Ripening: A Review. Lait 2000, 80, 293-324. [CrossRef]

63. Smit, G.; Smit, B.A.; Engels, W.J.M. Flavour Formation by Lactic Acid Bacteria and Biochemical Flavour Profiling of Cheese Products. FEMS Microbiol. Rev. 2005, 29, 591-610. [CrossRef]

64. Busscher, H.J. Specific and Non-Specific Interactions in Bacterial Adhesion to Solid Substrata. FEMS Microbio. Rev. 1987, 46, 9. [CrossRef]

65. An, Y.H.; Friedman, R.J. Concise Review of Mechanisms of Bacterial Adhesion to Biomaterial Surfaces. J. Biomed. Mater. Res. 1998, 43, 338-348. [CrossRef]

66. Laloy, E.; Vuillemard, J.-C.; El Soda, M.; Simard, R.E. Influence of the Fat Content of Cheddar Cheese on Retention and Localization of Starters. Int. Dairy J. 1996, 6, 729-740. [CrossRef]

67. Auty, M.A.E.; Gardiner, G.E.; McBrearty, S.J.; O'Sullivan, E.O.; Mulvihill, D.M.; Collins, J.K.; Fitzgerald, G.F.; Stanton, C.; Ross, R.P. Direct in Situ Viability Assessment of Bacteria in Probiotic Dairy Products Using Viability Staining in Conjunction with Confocal Scanning Laser Microscopy. Appl. Environ. Microbiol. 2001, 67, 420-425. [CrossRef]

68. Lopez, C.; Maillard, M.-B.; Briard-Bion, V.; Camier, B.; Hannon, J.A. Lipolysis during Ripening of Emmental Cheese Considering Organization of Fat and Preferential Localization of Bacteria. J. Agric. Food Chem. 2006, 54, 5855-5867. [CrossRef]

69. Lopez, C.; Camier, B.; Gassi, J.-Y. Development of the Milk Fat Microstructure during the Manufacture and Ripening of Emmental Cheese Observed by Confocal Laser Scanning Microscopy. Int. Dairy J. 2007, 17, 235-247. [CrossRef]

70. García-Cano, I.; Rocha-Mendoza, D.; Kosmerl, E.; Jiménez-Flores, R. Purification and Characterization of a PhospholipidHydrolyzing Phosphoesterase Produced by Pediococcus Acidilactici Isolated from Gouda Cheese. J. Dairy Sci. 2020, S0022030220301818. [CrossRef] [PubMed]

71. Moe, K.M.; Faye, T.; Abrahamsen, R.K.; Østlie, H.M.; Skeie, S. Growth and Survival of Cheese Ripening Bacteria on Milk Fat Globule Membrane Isolated from Bovine Milk and Its Monosaccharides. Int. Dairy J. 2012, 25, 29-35. [CrossRef]

72. Martinovic, A.; Moe, K.M.; Romeih, E.; Aideh, B.; Vogensen, F.K.; Østlie, H.; Skeie, S. Growth of Adjunct Lactobacillus Casei in Cheddar Cheese Differing in Milk Fat Globule Membrane Components. Int. Dairy J. 2013, 31, 70-82. [CrossRef]

73. Jiménez-Flores, R.; Brisson, G. The Milk Fat Globule Membrane as an Ingredient: Why, How, When? Dairy Sci. Technol. 2008, 88, 5-18. [CrossRef] 
74. Ly, M.H.; Vo, N.H.; Le, T.M.; Belin, J.-M.; Waché, Y. Diversity of the Surface Properties of Lactococci and Consequences on Adhesion to Food Components. Colloids Surf. B 2006, 52, 149-153. [CrossRef]

75. Brisson, G.; Payken, H.F.; Sharpe, J.P.; Jiménez-Flores, R. Characterization of Lactobacillus Reuteri Interaction with Milk Fat Globule Membrane Components in Dairy Products. J. Agric. Food Chem. 2010, 58, 5612-5619. [CrossRef] [PubMed]

76. Guerin, J.; Soligot, C.; Burgain, J.; Huguet, M.; Francius, G.; El-Kirat-Chatel, S.; Gomand, F.; Lebeer, S.; Le Roux, Y.; Borges, F.; et al. Adhesive Interactions between Milk Fat Globule Membrane and Lactobacillus Rhamnosus GG Inhibit Bacterial Attachment to Caco-2 TC7 Intestinal Cell. Colloids Surf. B 2018, 167, 44-53. [CrossRef]

77. Patton, S.; Gendler, S.J.; Spicer, A.P. The Epithelial Mucin, MUC1, of Milk, Mammary Gland and Other Tissues. Biochim. Biophys. Acta 1995, 1241, 407-423. [CrossRef]

78. Recio, I.; Moreno, F.J.; López-Fandiño, R. Glycosylated dairy components: Their roles in nature and ways to make use of their biofunctionality in dairy products. In Dairy-Derived Ingredients; Elsevier: Amsterdam, The Netherlands, 2009; pp. 170-211. ISBN 978-1-84569-465-4.

79. Gupta, V.K.; Tuohy, M.G.; O’Donovan, A.; Lohani, M. (Eds.) Biotechnology of Bioactive Compounds: Sources and Applications; Wiley-Blackwell: Chichester, UK; Hoboken, NJ, USA, 2015; ISBN 978-1-118-73344-8.

80. Verma, A.; Ghosh, T.; Bhushan, B.; Packirisamy, G.; Navani, N.K.; Sarangi, P.P.; Ambatipudi, K. Characterization of Difference in Structure and Function of Fresh and Mastitic Bovine Milk Fat Globules. PLoS ONE 2019, 14, e0221830. [CrossRef]

81. Shahriar, F.; Ngeleka, M.; Gordon, J.R.; Simko, E. Identification by Mass Spectroscopy of F4ac-Fimbrial-Binding Proteins in Porcine Milk and Characterization of Lactadherin as an Inhibitor of F4ac-Positive Escherichia Coli Attachment to Intestinal Villi in Vitro. Dev. Comp. Immunol. 2006, 30, 723-734. [CrossRef] [PubMed]

82. Zhang, L.; García-Cano, I.; Jiménez-Flores, R. Characterization of Adhesion between Limosilactobacillus Reuteri and Milk Phospholipids by Density Gradient and Gene Expression. JDS Commun. 2020, S2666910220300326. [CrossRef]

83. Miyoshi, Y.; Okada, S.; Uchimura, T.; Satoh, E. A Mucus Adhesion Promoting Protein, MapA, Mediates the Adhesion of Lactobacillus Reuteri to Caco-2 Human Intestinal Epithelial Cells. Biosci. Biotechnol. Biochem. 2006, 70, 1622-1628. [CrossRef]

84. Hsueh, H.-Y.; Yueh, P.-Y.; Yu, B.; Zhao, X.; Liu, J.-R. Expression of Lactobacillus Reuteri Pg4 Collagen-Binding Protein Gene in Lactobacillus Casei ATCC 393 Increases Its Adhesion Ability to Caco-2 Cells. J. Agric. Food Chem. 2010, 58, 12182-12191. [CrossRef] [PubMed]

85. Jensen, H.; Roos, S.; Jonsson, H.; Rud, I.; Grimmer, S.; van Pijkeren, J.-P.; Britton, R.A.; Axelsson, L. Role of Lactobacillus Reuteri Cell and Mucus-Binding Protein A (CmbA) in Adhesion to Intestinal Epithelial Cells and Mucus in Vitro. Microbiology 2014, 160, 671-681. [CrossRef]

86. Rocha-Mendoza, D.; Kosmerl, E.; Miyagusuku-Cruzado, G.; Giusti, M.M.; Jiménez-Flores, R.; García-Cano, I. Growth of Lactic Acid Bacteria in Milk Phospholipids Enhances Their Adhesion to Caco-2 Cells. J. Dairy Sci. 2020, S0022030220305385. [CrossRef] [PubMed]

87. Zhang, L.; Chichlowski, M.; Gross, G.; Holle, M.; lbarra-Sánchez, L.A.; Wang, S.; Miller, M.J. Milk Fat Globule Membrane Protects Lactobacillus Rhamnosus GG from Bile Stress by Regulating Exopolysaccharide Production and Biofilm Formation. J. Agric. Food Chem. 2020. [CrossRef] [PubMed]

88. Ortega-Anaya, J.; Marciniak, A.; Jimenez-Flores, R. Milk Fat Globule Membrane Phospholipids Modify Adhesion of Lactobacillus to Mucus-Producing Caco-2/Goblet Cells by Altering the Cell Envelope. Manuscript in Preparation.

89. Quinn, E.M.; Slattery, H.; Thompson, A.P.; Kilcoyne, M.; Joshi, L.; Hickey, R.M. Mining Milk for Factors Which Increase the Adherence of Bifidobacterium Longum Subsp. Infantis to Intestinal Cells. Foods 2018, 7, 196. [CrossRef] [PubMed]

90. Morifuji, M.; Kitade, M.; Oba, C.; Fukasawa, T.; Kawahata, K.; Yamaji, T.; Manabe, Y.; Sugawara, T. Milk Fermented by Lactic Acid Bacteria Enhances the Absorption of Dietary Sphingomyelin in Rats. Lipids 2017, 52, 423-431. [CrossRef] [PubMed]

91. Li, X.; Peng, Y.; Li, Z.; Christensen, B.; Heckmann, A.B.; Stenlund, H.; Lönnerdal, B.; Hernell, O. Feeding Infants Formula With Probiotics or Milk Fat Globule Membrane: A Double-Blind, Randomized Controlled Trial. Front. Pediatr. 2019, 7, 347. [CrossRef] [PubMed]

92. Benyacoub, J.; Blum-Sperisen, S.; Bosco, M.N.; Bovetto, L.; Jean, R.; Bureau-Franz, I.; Donnet-Hughes, A.; Schiffrin, E.; Favre, L. Infant Formula with Probiotics and Milk Fat Globule Membrane Components. U.S. Patent WO2011069987A1, 16 June 2011.

93. Nieto-Ruiz, A.; García-Santos, J.A.; Bermúdez, M.G.; Herrmann, F.; Diéguez, E.; Sepúlveda-Valbuena, N.; García, S.; Miranda, M.T.; De-Castellar, R.; Rodríguez-Palmero, M.; et al. Cortical Visual Evoked Potentials and Growth in Infants Fed with Bioactive Compounds-Enriched Infant Formula: Results from COGNIS Randomized Clinical Trial. Nutrients 2019, 11, 2456. [CrossRef]

94. Nieto-Ruiz, A.; Diéguez, E.; Sepúlveda-Valbuena, N.; Catena, E.; Jiménez, J.; Rodríguez-Palmero, M.; Catena, A.; Miranda, M.T.; García-Santos, J.A.G.; Bermúdez, M.; et al. Influence of a Functional Nutrients-Enriched Infant Formula on Language Development in Healthy Children at Four Years Old. Nutrients 2020, 12, 535. [CrossRef]

95. Martinez, R.C.R.; Aynaou, A.-E.; Albrecht, S.; Schols, H.A.; De Martinis, E.C.P.; Zoetendal, E.G.; Venema, K.; Saad, S.M.I.; Smidt, H. In Vitro Evaluation of Gastrointestinal Survival of Lactobacillus Amylovorus DSM 16698 Alone and Combined with Galactooligosaccharides, Milk and/or Bifidobacterium Animalis Subsp. Lactis Bb. Int. J. Food Microbiol. 2011, 149, 152-158. [CrossRef]

96. Bezkorovainy, A. Probiotics: Determinants of Survival and Growth in the Gut. Am. J. Clin. Nutr. 2001, 73, 399s-405s. [CrossRef] [PubMed] 
97. Su, P.; Henriksson, A.; Mitchell, H. Prebiotics Enhance Survival and Prolong the Retention Period of Specific Probiotic Inocula in an in Vivo Murine Model. J. Appl. Microbiol. 2007, 103, 2392-2400. [CrossRef] [PubMed]

98. Wang, J.; Guo, Z.; Zhang, Q.; Yan, L.; Chen, W.; Liu, X.-M.; Zhang, H.-P. Fermentation Characteristics and Transit Tolerance of Probiotic Lactobacillus Casei Zhang in Soymilk and Bovine Milk during Storage. J. Dairy Sci. 2009, 92, 2468-2476. [CrossRef]

99. Limoli, D.H.; Jones, C.J.; Wozniak, D.J. Bacterial Extracellular Polysaccharides in Biofilm Formation and Function. Microbiol. Spectrum 2015, 3, 19. [CrossRef]

100. Fanning, S.; Hall, L.J.; Cronin, M.; Zomer, A.; MacSharry, J.; Goulding, D.; O'Connell Motherway, M.; Shanahan, F.; Nally, K.; Dougan, G.; et al. Bifidobacterial Surface-Exopolysaccharide Facilitates Commensal-Host Interaction through Immune Modulation and Pathogen Protection. Proc. Natl. Acad. Sci. USA 2012, 109, 2108-2113. [CrossRef] [PubMed]

101. Ortega-Anaya, J.; Rocha-Mendoza, D.; García-Cano, I.; Jimenez-Flores, R. Effect of Milk Fat Globule Membrane Phospholipids in the Adherence of Probiotic Lactic Acid Bacteria- Modeling Interactions in the Human Gut. In Proceedings of the American Dairy Science Association Annual Meeting, Cincinnati, OH, USA, 23-26 June 2019.

102. Zmora, N.; Zilberman-Schapira, G.; Suez, J.; Mor, U.; Dori-Bachash, M.; Bashiardes, S.; Kotler, E.; Zur, M.; Regev-Lehavi, D.; Brik, R.B.-Z.; et al. Personalized Gut Mucosal Colonization Resistance to Empiric Probiotics Is Associated with Unique Host and Microbiome Features. Cell 2018, 174, 1388-1405.e21. [CrossRef]

103. Fan, W.; Huo, G.; Li, X.; Yang, L.; Duan, C.; Wang, T.; Chen, J. Diversity of the Intestinal Microbiota in Different Patterns of Feeding Infants by Illumina High-Throughput Sequencing. World J. Microbiol. Biotechnol. 2013, 29, 2365-2372. [CrossRef] [PubMed]

104. Tokuhara, D.; Kurashima, Y.; Kamioka, M.; Nakayama, T.; Ernst, P.; Kiyono, H. A Comprehensive Understanding of the Gut Mucosal Immune System in Allergic Inflammation. Allergol. Int. 2019, 68, 17-25. [CrossRef]

105. Norris, G.H.; Porter, C.M.; Jiang, C.; Millar, C.L.; Blesso, C.N. Dietary Sphingomyelin Attenuates Hepatic Steatosis and Adipose Tissue Inflammation in High-Fat-Diet-Induced Obese Mice. J. Nutr. Biochem. 2017, 40, 36-43. [CrossRef] [PubMed]

106. Tanaka, K.; Hosozawa, M.; Kudo, N.; Yoshikawa, N.; Hisata, K.; Shoji, H.; Shinohara, K.; Shimizu, T. The Pilot Study: Sphingomyelin-Fortified Milk Has a Positive Association with the Neurobehavioural Development of Very Low Birth Weight Infants during Infancy, Randomized Control Trial. Brain Dev. 2013, 35, 45-52. [CrossRef] [PubMed]

107. Oshida, K.; Shimizu, T.; Takase, M.; Tamura, Y.; Shimizu, T.; Yamashiro, Y. Effects of Dietary Sphingomyelin on Central Nervous System Myelination in Developing Rats. Pediatr. Res. 2003, 53, 589-593. [CrossRef]

108. Oba, C.; Morifuji, M.; Ichikawa, S.; Ito, K.; Kawahata, K.; Yamaji, T.; Asami, Y.; Itou, H.; Sugawara, T. Dietary Milk Sphingomyelin Prevents Disruption of Skin Barrier Function in Hairless Mice after UV-B Irradiation. PLoS ONE 2015, 10. [CrossRef]

109. Le Huërou-Luron, I.; Bouzerzour, K.; Ferret-Bernard, S.; Ménard, O.; Le Normand, L.; Perrier, C.; Le Bourgot, C.; Jardin, J.; Bourlieu, C.; Carton, T.; et al. A Mixture of Milk and Vegetable Lipids in Infant Formula Changes Gut Digestion, Mucosal Immunity and Microbiota Composition in Neonatal Piglets. Eur. J. Nutr. 2018, 57, 463-476. [CrossRef]

110. Statovci, D.; Aguilera, M.; MacSharry, J.; Melgar, S. The Impact of Western Diet and Nutrients on the Microbiota and Immune Response at Mucosal Interfaces. Front. Immunol. 2017, 8, 838. [CrossRef]

111. Lee, H.; Slupsky, C.M.; Heckmann, A.B.; Christensen, B.; Peng, Y.; Li, X.; Hernell, O.; Lönnerdal, B.; Li, Z. Milk Fat Globule Membrane as a Modulator of Infant Metabolism and Gut Microbiota: A Formula Supplement Narrowing the Metabolic Differences between Breastfed and Formula-Fed Infants. Mol. Nutr. Food Res. 2020, 2000603. [CrossRef]

112. He, X.; Parenti, M.; Grip, T.; Lönnerdal, B.; Timby, N.; Domellöf, M.; Hernell, O.; Slupsky, C.M. Fecal Microbiome and Metabolome of Infants Fed Bovine MFGM Supplemented Formula or Standard Formula with Breast-Fed Infants as Reference: A Randomized Controlled Trial. Sci. Rep. 2019, 9. [CrossRef] [PubMed]

113. Garcia-Rodenas, C.L.; Bergonzelli, G.; Rochat, F.; Turini, M.E.; Corthesy-Theulaz, I.; Cherbut, C. Nutritional Formula for Optimal Gut Barrier Function. U.S. Patent US2004112509A2, 29 December 2004.

114. Mikulic, J.; Longet, S.; Favre, L.; Benyacoub, J.; Corthesy, B. Secretory IgA in Complex with Lactobacillus Rhamnosus Potentiates Mucosal Dendritic Cell-Mediated Treg Cell Differentiation via TLR Regulatory Proteins, RALDH2 and Secretion of IL-10 and TGF- $\beta$. Cell Mol. Immunol. 2017, 14, 546-556. [CrossRef]

115. Holland, D.; Chang, L.; Ernst, T.M.; Curran, M.; Buchthal, S.D.; Alicata, D.; Skranes, J.; Johansen, H.; Hernandez, A.; Yamakawa, R.; et al. Structural Growth Trajectories and Rates of Change in the First 3 Months of Infant Brain Development. JAMA Neurol. 2014, 71, 1266. [CrossRef]

116. Stiles, J.; Jernigan, T.L. The Basics of Brain Development. Neuropsychol. Rev. 2010, 20, 327-348. [CrossRef]

117. Schneider, N.; Garcia-Rodenas, C.L. Early Nutritional Interventions for Brain and Cognitive Development in Preterm Infants: A Review of the Literature. Nutrients 2017, 9, 187. [CrossRef] [PubMed]

118. Deoni, S.; Dean, D.; Joelson, S.; O’Regan, J.; Schneider, N. Early Nutrition Influences Developmental Myelination and Cognition in Infants and Young Children. NeuroImage 2018, 178, 649-659. [CrossRef] [PubMed]

119. Li, F.; Wu, S.S.; Berseth, C.L.; Harris, C.L.; Richards, J.D.; Wampler, J.L.; Zhuang, W.; Cleghorn, G.; Rudolph, C.D.; Liu, B.; et al. Improved Neurodevelopmental Outcomes Associated with Bovine Milk Fat Globule Membrane and Lactoferrin in Infant Formula: A Randomized, Controlled Trial. J. Pediatr. 2019, S0022347619310881. [CrossRef]

120. Schipper, L.; van Dijk, G.; Broersen, L.M.; Loos, M.; Bartke, N.; Scheurink, A.J.; van der Beek, E.M. A Postnatal Diet Containing Phospholipids, Processed to Yield Large, Phospholipid-Coated Lipid Droplets, Affects Specific Cognitive Behaviors in Healthy Male Mice. J. Nutr. 2016, 146, 1155-1161. [CrossRef] [PubMed] 
121. Moukarzel, S.; Dyer, R.A.; Garcia, C.; Wiedeman, A.; Boyce, G.; Weinberg, J.; Keller, B.O.; Elango, R.; Innis, S.M. Milk Fat Globule Membrane Supplementation in Formula-Fed Rat Pups Improves Reflex Development and May Alter Brain Lipid Composition. Sci. Rep. 2018, 8, 9. [CrossRef]

122. Brink, L.R.; Gueniot, J.P.; Lönnerdal, B. Effects of Milk Fat Globule Membrane and Its Various Components on Neurologic Development in a Postnatal Growth Restriction Rat Model. J. Nutr. Biochem. 2019, 9. [CrossRef] [PubMed]

123. Thompson, R.S.; Roller, R.; Mika, A.; Greenwood, B.N.; Knight, R.; Chichlowski, M.; Berg, B.M.; Fleshner, M. Dietary Prebiotics and Bioactive Milk Fractions Improve NREM Sleep, Enhance REM Sleep Rebound and Attenuate the Stress-Induced Decrease in Diurnal Temperature and Gut Microbial Alpha Diversity. Front. Behav. Neurosci. 2017, 10. [CrossRef]

124. Timby, N.; Domellöf, E.; Hernell, O.; Lönnerdal, B.; Domellöf, M. Neurodevelopment, Nutrition, and Growth until 12 Mo of Age in Infants Fed a Low-Energy, Low-Protein Formula Supplemented with Bovine Milk Fat Globule Membranes: A Randomized Controlled Trial. Am. J. Clin. Nutr. 2014, 99, 860-868. [CrossRef] [PubMed]

125. Tognini, P. Gut Microbiota: A Potential Regulator of Neurodevelopment. Front. Cell. Neurosci. 2017, 11. [CrossRef]

126. Appleton, J. The Gut-Brain Axis: Influence of Microbiota on Mood and Mental Health. Integr. Med. $2018,17,28-32$.

127. O’Mahony, S.M.; Neufeld, K.-A.M.; Waworuntu, R.V.; Pusceddu, M.M.; Manurung, S.; Murphy, K.; Strain, C.; Laguna, M.C.; Peterson, V.L.; Stanton, C.; et al. The Enduring Effects of Early-Life Stress on the Microbiota-Gut-Brain Axis Are Buffered by Dietary Supplementation with Milk Fat Globule Membrane and a Prebiotic Blend. Eur. J. Neurosci. 2020, 51, 1042-1058. [CrossRef] [PubMed]

128. Li, T.; Gao, J.; Du, M.; Song, J.; Mao, X. Milk Fat Globule Membrane Attenuates High-Fat Diet-Induced Obesity by Inhibiting Adipogenesis and Increasing Uncoupling Protein 1 Expression in White Adipose Tissue of Mice. Nutrients 2018, 10, 331. [CrossRef]

129. Nicolson, G.L.; Ash, M.E. Membrane Lipid Replacement for Chronic Illnesses, Aging and Cancer Using Oral Glycerolphospholipid Formulations with Fructooligosaccharides to Restore Phospholipid Function in Cellular Membranes, Organelles, Cells and Tissues. Biochim. Biophys. Acta 2017, 1859, 1704-1724. [CrossRef]

130. García-Cano, I.; Rocha-Mendoza, D.; Ortega-Anaya, J.; Wang, K.; Kosmerl, E.; Jiménez-Flores, R. Lactic Acid Bacteria Isolated from Dairy Products as Potential Producers of Lipolytic, Proteolytic and Antibacterial Proteins. Appl. Microbiol. Biotechnol. 2019. [CrossRef] [PubMed]

131. Manasian, P.; Bustos, A.-S.; Pålsson, B.; Håkansson, A.; Peñarrieta, J.M.; Nilsson, L.; Linares-Pastén, J.A. First Evidence of Acyl-Hydrolase/Lipase Activity from Human Probiotic Bacteria: Lactobacillus Rhamnosus GG and Bifidobacterium Longum NCC. Front. Microbiol. 2020, 11. [CrossRef] [PubMed]

132. Soda, M.E.; Wahab, H.A.E.; Ezzat, N.; Desmazeaud, M.J.; Ismail, A. The Esterolytic and Lipolytic Activities of the Lactobacilli. II. Detection of the Esterase System of Lactobacillus Helveticus, Lactobacillus Bulgaricus. Lactobacillus Lactis and Lactobacillus Acidophilus. Lait 1986, 66, 431-443. [CrossRef] 